\title{
ÁLVARO SALVADOR: POESÍA EN Y ANTE LA HISTORIA (ENTREVISTA EN GRANADA, 26-11-2016)
}

\author{
PABLO CARRIEDO CASTRO \\ Colegio Sierra-Pambley (León)
}

Dedicado a Tony Geist

\section{SERIO APRENDIZ DE POETA}

Pablo Carriedo: Quería preguntarle en primer lugar sobre algunos de los elementos de su mitología generacional que plantea en la novela autobiográfica El prisionero a muerte ${ }^{1}$ en la que, entre otros aspectos, hace también un repaso de su infancia y su juventud. Usted asegura que sus primeros recuerdos están muy asociados al mundo agrario y el campo. ¿Cómo recuerda aquella época?

Álvaro Salvador: Bueno. Yo vivía en un carmen. Vivir en un carmen era como vivir en un jardín y, para un niño, más todavía: teníamos ocas, teníamos peces, el perro Káiser, en fin, animales. Granada era entonces todavía muy rural. Era un contacto un poco más artificial que en el propio campo, pero no había una gran diferencia. Luego, cuando nos mudamos al ensanche de Recogidas en la parte sur de la ciudad, a la calle Pedro Antonio de Alarcón 21 (que ahora, estos últimos años, es donde se ha concentrado ahí «la movida» de la gente joven, los bares y tal), aquello era entonces La Vega. Estaban trazadas las calles del ensanche, pero había sólo dos o tres casas, dos o tres bloques. Uno de ellos era el nuestro y justo enfrente estaba el de Javier Egea, la casa de Javier. Detrás estaba la Huerta de San Vicente, que permanecía aún como

\footnotetext{
${ }^{1}$ Salvador, A., El prisionero a muerte, Sevilla, Renacimiento, 2006.
} 
una huerta propiamente. Recuerdo que al lado había una casería con sus acequias... Era realmente como estar en el campo. Esa mezcla entre campo y ciudad, sí, ha sido constante en mí hasta casi los treinta años. Porque además, los veranos y gran parte de algunos inviernos antes de comenzar el bachillerato, los pasé en una finca que mis padres tenían en Cúllar y en el mismo pueblo, al norte de la provincia. Fíjate. Todavía en el año ochenta, invitamos a Jaime [Gil de Biedma] a dar una conferencia. Él venía por primera vez a Granada y lo instalamos aquí cerca, en el Hotel Alhambra Palace, en un edificio de estilo orientalista que levantaron en los años veinte para las visitas del rey. Desde allí hay una vista enorme de La Vega de Granada. Al salir al balcón, Jaime se quedó pensativo (como a veces le pasaba, en medio de un flash poético) y nos dijo «esta ciudad está amenazada por el campo» [ríe]. Y estamos hablando ya de los años ochenta.

PC: Esa mudanza al piso de la calle Pedro Antonio de Alarcón, en el ensanche, coincide con su entrada en el bachillerato y su adolescencia. Parece que entonces llegan algunos cambios tecnológicos y culturales como la radio y la televisión, el cine, los álbumes y cómics; algunos elementos de los que habla Castellet en su descripción de los Nueve Novísimos. ¿Se reconoce usted en ellos?

ÁS: Sí, la cultura camp y todo eso. Bueno..., sí. En ese sentido, sí. Fue nuestra formación. Hubo, creo yo, otros elementos que fueron más definidores como la revolución de las formas juveniles y la música. Aunque antes sí; los cómic, el cine... En realidad, todo fue bastante progresivo. Tal vez lo primero, el primer elemento cultural mediático que yo recuerdo, fue el tebeo. Yo aprendí a leer en los tebeos. Dábamos clase y aprendíamos a leer en la escuela, claro; pero la auténtica conciencia de estar leyendo, estar sentado en casa y darme cuenta de que leía, esa sensación yo la tuve con los álbumes. Todos leíamos tebeos, los cambiábamos y tal. Sí. Luego fue la radio. Recuerdo especialmente los programas de Diego Valor y los programas humorísticos como el de Pepe Iglesias, «El Zorro». Y ya, más tarde, la televisión. Íbamos de chicos a casa de los vecinos que tenían tele a ver el programa de Franz Johan los sábados o alguna película. Y, claro, el cine. En el momento en que crecí un poco iba al cine con mi familia o con los compañeros. Íbamos a las salas comerciales y también a las funciones del colegio, que hacían sesiones los fines de semana con películas de Charlie Chaplin, El gordo y El flaco, las películas de Tarzán. Ese tipo de cine. Y, bueno, lo siguiente fue ya la revolución de la música. La música pop.

PC: La música es un elemento muy importante tanto en su trayectoria personal, como también en la poética. De hecho, fue usted miembro guitarrista de varias bandas, ${ }^{2}$ trabajó como

${ }^{2}$ «Tras la guitarra, vino el pequeño tocadiscos y la formación del primer grupo musical, The Cat Savages [...] el repertorio fue Beatles en su totalidad, empezando por Twist and Shout [...] Al año siguiente constituimos un grupo más serio y con mayores ambiciones, Los Topos. Nuestra idea era continuar 
disc-jockey. Y fue también reportero para una revista musical.

ÁS: Sí, la revista Mundo Joven. La verdad es que era una revista muy interesante. Tal vez la más importante en aquel momento. El redactor jefe de la revista era José María Iñigo y el director era Jesús Picatoste, un periodista que luego fue jefe del gabinete de prensa de Adolfo Suárez. Uno de los redactores era Román Orozco que ha sido con el tiempo director de El País de Andalucía. En fin, había un plantel de buenos periodistas; una plantilla muy buena. Y no sólo se hacían reportajes de música, también escribíamos buenos reportajes de viajes, reseñas de libros; aunque lo más gordo era la música, claro.

PC: En algún testimonio ha comentado ya que, antes de entrar en la Universidad, trabajar en Mundo Joven le facilita el contacto con distintos ambientes rebeldes o alternativos de la ciudad de Granada, ambientes musicales por un lado, en los que se desenvuelve como discjockey y reportero; $y$, por otro, también ambientes políticos.

ÁS: La música fue antes; fue primero la música. En mi caso (y creo que en el de muchos de los chicos de mi generación) fue antes la rebeldía que la conciencia política, que llega ya en el periodo universitario. La rebeldía empieza cuando cumplimos trece o catorce años: escuchar a los Beatles y a los Rolling Stones, dejarse el pelo largo, tener ropa distinta... Era un poco introducir una imagen distinta que, en España y entonces, era muy chocante. Porque hasta ese momento los chicos jóvenes lo que intentaban era parecerse a los mayores: se vestía uno con traje y con corbata. Todo muy rígido, muy gris, muy marrón. La verdad es que fue un cambio tremendo; y con una cierta ambigüedad. Claro, en un país tan machista eso creaba inquietud. Las personas mayores, las personas de bien no lo toleraban. No querían tolerarlo. Nos insultaban [ríe]. Nos decían: «Pélate que pareces una tía». La concienciación política fue ya más bien en la universidad. Bueno... Recuerdo que en el preuniversitario asistí a una primera reunión política. Esto no está bien decirlo hoy -según se tome-, aunque en realidad es la evolución política de casi todo el mundo en esa misma época. Verás. Fuimos a una reunión de lo que se llamaba la Falange reconstituida. Era una «Falange de izquierdas»o «Falange social» y estaban montando grupos para acercarse a los estudiantes. Me acuerdo de un chico falangista (que luego sería un líder del PCE durante la Transición), que nos dio un par de charlas. Nos dio sólo un par porque ya en la segunda, en fin, nos dimos cuenta de que aquello era más de lo mismo; no salía del mismo círculo vicioso. En el fondo, cómo te diría... teníamos unas inquietudes políticas que no sabíamos cómo canalizar o por dónde. La gente iba allí donde se movía algo, donde había un poquito de margen. Más tarde -yo diría que la mayoría- fuimos evolucionando hacia posiciones de auténtico cambio. Es parecido a lo que cuenta Castellet en sus memorias: al principio

la línea de música pop más intelectual y creativa que en España habían inaugurado grupos como Los Brincos, Los Salvajes o Lone Star». Salvador, A., El prisionero a muerte, Sevilla, Renacimiento, 2006, p. 146. 
se acercan un poco a los ambientes de la «Falange socialdemócrata» de los que luego, claro, terminaron separándose. O como el caso también de Dionisio Ridruejo. En fin, también sucedió así en Granada, aunque a pequeña escala. En mi caso, al entrar en la Universidad es cuando nos ponemos en contacto con gente que está organizada en torno al Sindicato Independiente de Estudiantes, un sindicato auténticamente democrático, y es ahí donde conocemos ya algunos grupos de izquierda.

\section{PC: ¿Cómo era entonces la atmósfera política de la izquierda?}

ÁS: Todo aquello era... ¿cómo te diría? Eran, en principio, grupos pro-izquierdistas; grupos muy desarticulados y espontáneos. Algunos derivaron después en formaciones más serias como el Partido del Trabajo o el Movimiento Comunista. Ese tipo deagrupaciones.

\section{PC: ¿No les interesaba entonces la orientación del PCE o sus propuestas?}

Ás: El Partido Comunista era en aquella época muy obrerista. Es decir, para nosotros parecía que tenía unas connotaciones muy ligadas con el obrerismo, con el mundo obrero, que no era exactamente el nuestro. ${ }^{3}$ Nosotros teníamos más que ver con el «espíritu de mayo» que venía de Francia y nos identificábamos con lo que estaban escribiendo en ese momento gente como Marcuse, Althusser o Sartre también. Buscábamos algo un poco más radical desde el punto de vista del trabajo intelectual. ${ }^{4}$ En la Universidad el PCE empieza a interesar más tarde. Especialmente en los años de la Transición; en los años setenta. Después del atentado de Carrero Blanco, yo diría. Es entonces cuando el movimiento estudiantil empieza a aproximarse al Partido Comunista y ya en esos años se integra, por decirlo así, casi totalmente en él. Otros no. Otros siguieron un poco al margen. Y algunos llegaron a radicalizarse mucho; mucho. Incluso aquí, en Andalucía, algunos apoyaban a los abertzales y a la ETA. Hubo candidaturas y sacaron votos y todo. Y otros próximos al GRAPO o el FRAP. Recuerdo que en un momento, alguien nos llevó a una reunión del PT. Había venido un chico de Valencia (creo que era pareja de una colega y que luego llegó a ser dirigente socialista;

\footnotetext{
${ }^{3}$ «Una vez más, hoy día, se comprueba que la clase obrera está en el centro de las transformaciones que se producen en todas partes de la tierra, y que su actividad condiciona y determina el progreso y el desarrollo social. Al liberarse a sí misma, libera a toda la humanidad, y ello a causa del lugar que ocupa en el proceso productivo. Es la única clase capaz de aglutinar a todos los asalariados, a todas las fuerzas de progreso, para acabar con la explotación del hombre por el hombre, para construir la sociedad sin clases». López Salinas, A., La Alianza de las Fuerzas del Trabajo y la Cultura, Madrid, Forma Ediciones, 1977, p. 43.

${ }^{4}$ «De los numerosos acontecimientos inesperados de fines de la década de los sesenta [...] el movimiento de mayo de 1968 en Francia fue sin duda el más sorprendente y, para los intelectuales de izquierda, probablemente el más excitante. [...] Pareció demostrar algo en que prácticamente ningún revolucionario de más de veinticinco años creía: que era posible llevar a cabo una revolución en un país industrial avanzado en condiciones de paz, prosperidad y aparente estabilidad política. Lo habría logrado un movimiento popular de base, sin la ayuda de nadie dentro de la estructura de poder. Y fueron los estudiantes los que iniciaron e inspiraron ese movimiento haciéndose portavoces de él en momentos cruciales de su desarrollo». Hobsbaum, E., Revolucionarios, Barcelona, Editorial Crítica, 2003, p. 331.
} 
no me acuerdo de su nombre) y allí en la reunión nos sacó un revólver: «esto es lo que hay que hacer», decía. Porque estaban promocionando la «lucha armada». Y, bueno, en fin, esas cosas a mí y a otros muchos nos echaron para atrás. No era esa la línea que buscábamos. Yo creo que a partir de ahí, en esa época, comenzó a verse al PCE como un partido que iba realmente a ayudar en la normalización democrática. Se vio pronto la intención de Santiago Carrillo y el PCE fue creciendo.

PC: Esa rebeldía en las formas y las actitudes de vida, unida a la rebeldía política, se asocian en la Universidad en varios proyectos muy interesantes, como la revista Tragaluz, u otros ligados también a la música, con figuras como Joaquín Sabina o Carlos Cano.

ÁS: Todo estaba muy unido, sí. Fíjate. En realidad, yo no abandoné la música hasta el año 1970 o 1971. Seguía estando vinculado a los ambientes musicales y lo mismo les pasaba a Carlos y a Joaquín. Yo era un poco más dogmático en mis gustos; a mí me gustaba mucho el rock and roll y el «beat». Joaquín era mucho más Bob Dylan, que siempre fue su modelo - la cosa folk y tal-, e incluso vestía como él con chaleco y botas. A Carlos le gustaba mucho la canción tradicional, sobre todo la canción sudamericana que en esos años tenía cantantes muy influyentes y muy comprometidos (y además quedabas muy bien al cantarlos [sonríe]): Atahualpa Jupanqui, Víctor Jara, Mercedes Sosa... Recuerdo que hacíamos lecturas en la Casa de América. Había en Granada una sucursal del Instituto de Cultura Hispánica de Madrid, impulsada por Luis Rosales. Carlos y Joaquín venían con sus guitarras, recitábamos poemas y cantábamos... En un momento determinado, por circunstancias políticas, Joaquín se tuvo que marchar. Se fue a Inglaterra. Para ganarse la vida en Londres, acentuó su faceta musical, empezó a cantar en bares y allí se hizo profesional. Sí. Estaba todo muy unido: literatura, política, poesía, la canción. Todo junto.

PC: Usted y otros autores granadinos, como Andrés Soria Olmedo o Luis García Montero, han descrito en algún momento el ambiente cultural de la ciudad en aquella época como fuertemente represivo. Han hablado de las resistencias que encontraban sus proyectos, algo de provincianismo y ciertas miserias culturales.

Ás: Antes de la Transición las resistencias eran sobre todo de la censura. La censura nos fastidiaba cada dos por tres. Juan de Loxa tuvo una serie de problemas con ellos con Poesía 70. ${ }^{5} \mathrm{Y}$ nosotros también. En nuestro caso, al ser una revista universitaria teníamos más fácil solucionar algunos problemas. Me acuerdo que tuvimos una multa y que nos congelaron el permiso para sacar el último número de la revista. Don Antonio Gallego Morel, que era nuestro catedrático y en aquel momento tenía algún tipo de

\footnotetext{
${ }^{5}$ «En 1965, Juan de Loxa inauguraba en Radio Popular de Granada el programa Poesía 70 (obtuvo el Premio Ondas en 1982 y hoy es un inapreciable y exhaustivo archivo fonográfico, a juicio de Miguel Gallego Roca), la primera de las series de empresas de agitación cultural que alentó este poeta». Soria Olmedo, A., Literatura en Granada. Poesía (1898-1998), Granada, Diputación de Granada, 2000, p. 82.
} 
cargo (no sé si era Delegado de Información y Turismo; en fin, algo del régimen), nos sacó del atolladero. Pero, sí, la resistencia era constante. En primer lugar porque a la mayoría de la sociedad no le interesaba mucho la cultura. Nadie te ayudaba, nadie te promocionaba, ni nadie te daba publicidad. Sobre todo, si querías decir ciertas cosas. Ahí venía el palo. Para sacar adelante Tragaluz tuvimos cierta suerte. El país se estaba moviendo a todos los niveles y se crearon ciertas grietas; ciertos espacios por donde te podías colar. Por ejemplo, tuvimos la suerte de que nuestro Rector era entonces Federico Mayor Zaragoza, un tipo muy liberal y muy joven además (había sacado la cátedra muy joven). Un tipo brillante. Fuimos a pedirle que nos diera dinero para hacer la revista y nos lo dio. Y por eso pudimos hacerla. Antonio Gallego también estaba ahí, metido en algo del régimen; pero, a la vez, tenía una mente abierta y procuraba ayudarte en la medida que podía. Pero era siempre con mucho esfuerzo y llegaba un momento que te cansabas. Pasó con Tragaluz. De pronto llegó un momento en que nos cansamos. Durante un año hicimos el programa en Radio Granada y eso sirvió para lanzarlo todo. Pero en cuanto llegaron los últimos cursos, cuarto y quinto, donde uno tenía que trabajar fuerte, ya no podíamos dedicar tanto tiempo, tanto esfuerzo a la revista, y lo dejamos. Con Letras del Sur pasó exactamente lo mismo. Yo diría que con Letras del Sur nos adelantamos cuatro años: hicimos la revista en 1978, pero si la hubiésemos sacado en 1982 hubiera durado diez años, que es lo que pasó con Olvidos [de Granada]. Hicimos un acto cuando salió el último número, con Pepe Caballero [Bonald] y con Fernando Quiñones. Pero, ¿qué pasaba? Pues que la Junta de Andalucía era todavía muy tímida. Era todavía la Junta pre-autonómica de la UCD y aquello no interesaba. ${ }^{6}$

PC: En ese medio ambiente, publica usted su primer libro poético, Y... [Premio Federico García Lorca. Universidad de Granada, 1971]. ¿Qué significó publicar ese libro con 21 años de edad?

Ás: Fue extraordinario, claro. Fue el momento de confirmar la vocación. Hasta ese momento, todo habían sido escarceos juveniles con los que, además, tuve serias dudas. En primer lugar, tuve mis dudas con la carrera. Durante todo un año la dejé y estuve trabajando de disc-jockey, haciendo otra vez música y haciendo teatro. Estuve a punto de irme a Madrid. Y es que, de pronto, la carrera me decepcionó. Había tenido buenos profesores, buenos catedráticos en el instituto: don Emilio Orozco, don Antonio Domínguez Ortiz. Los grandes. Al llegar a la Universidad, pensaba que iba a ser la maravilla, ¿no? Y no lo fue. Fueron los años en que la Universidad se masifica. De cincuenta personas que, más o menos, había en cada curso, de pronto pasaron a

\footnotetext{
${ }^{6}$ «José Manuel Caballero Bonald y Fernando Quiñones han participado en Granada en el acto de presentación del número seis de la revista Letras del Sur, bimestral de arte y literatura [...] también intervinieron los profesores Pablo Jauralde y Álvaro Salvador. Se hizo balance de los seis primeros números y se criticó duramente la falta de atención y ayuda oficial a este tipo de publicaciones». El País (29 de marzo de 1979), s.p.
} 
doscientas cincuenta con un grupo de mañana y otro de tarde. Los catedráticos venían el primer día, daban su lección magistral y el resto del tiempo nos daban clase los PNN. Había algunos buenos, pero otros muy malos. Yo me decepcioné un montón. Aquello no era lo que yo esperaba. De modo que estuve pensando si irme, a lo mejor, a Madrid a hacer teatro. Continué un tiempo con la música y tal; y eso sabiendo que no se me daba muy bien porque no tenía el oído suficiente.

PC: En algún texto el profesor Juan Carlos Rodríguez describe los inicios de su trayectoria en la poesía como letrista de música; no como «autor de canciones», sino como letrista, propiamente. ${ }^{7}$

ÁS: Eso viene de una anécdota que él conocía, porque la vivió también. Fue el año en que empezó a darme clase; el año 1971 o 1972. Gracias al Premio García Lorca, un amigo - que fue precisamente por el que yo desistí de ser músico-que se llamaba José Luis García Román, entró ese mismo año como guitarrista en el grupo Los Ángeles. Era un guitarrista maravilloso, con un oído excepcional (luego se mató en un accidente; se estrellaron con un coche y se mataron la mitad). Hasta ese momento, digamos, José Luis se había tomado mis veleidades poéticas de cachondeo. Pero cuando consigo el Premio García Lorca se interesó y me pidió que les escribiera unas letras para el grupo. «Tenemos una música»y tal; «no sabemos qué letra ponerle», etc. Les hice dos letras. Ellos me dieron un dinero - un dinero importante-, pero claro, con la ingenuidad que uno tiene en esa época, yo les cedí los derechos en lugar de ponerlas a mi nombre y registrarlas. En los créditos aparece el nombre de uno de ellos, creo que el de Agustín [Rodríguez]. Pero las letras son mías. Un chico de Sevilla que ha publicado un libro reciente sobre Los Ángeles, se enteró por alguien de que yo era el autor y lo corrigió. ${ }^{8}$ Además, se nota que esas letras son distintas a todas las demás. Son, digamos, letras más literarias. Por eso Juan Carlos decía lo de letrista, porque él lo sabía. Fernando Guzmán de la Universidad de Sevilla ha investigado esa etapa y ha hecho varios artículos sobre esos primeros poemas míos que él denomina «pop poesía»: los POPoemas. ${ }^{9}$

PC: Hay también en ese libro una exploración muy interesante de algunos otros aspectos de la rebelión estudiantil como la Guerra del Vietnam, las películas de Claude Lelouch o de Antonioni...

\footnotetext{
${ }^{7}$ Rodríguez, J.C., «La guarida inútil», prólogo a Salvador, A., Las cortezas del fruto, Madrid, Editorial Ayuso, 1980, pp. 13-25.

${ }^{8}$ Canciones «Sueños» (Réquiem, 1970) y «Te necesito»(Evolución, 1973). Díaz de la Guardia, F., Los Ángeles: una leyenda del pop español. Granada, Ramalama, 2006, pp. 168 y 211.

${ }^{9}$ Guzmán Simón, F., Granada y la revolución 70. Poetas y poéticas de la revista «Poesía 70», Granada, Comares, 2010. Y del mismo autor De «Tragaluz» a «Letras del Sur»: panorama de las revistas universitarias de la Transición en Granada (1968-1978). Granada, Universidad de Granada, 2011. Salvador A., PoPoemas [Prólogo y selección de Fernando Guzmán Simón], Granada, Dauro, 2014.
} 
ÁS: Sí, la Nouvelle Vague [ríe].

PC: En el año 1972 gana usted el Premio Nacional Universitario con el texto La mala crianza [Librería Anticuaria El Guadalhorce; Málaga, 1974 (2 $2^{a}$ ed., 1978)] en el que parece insistir en los mismos elementos generacionales de ruptura y rebeldía. Sin embargo, no sé si podría hablarse ya de un cambio consciente, porque en el prólogo define expresamente la poesía como un tipo de "producción ideológica» y habla ya de Freud y de Althusser, en la línea de lo que será después La otra sentimentalidad.

ÁS: Ahí ya estamos muy imbuidos de las teorías de Juan Carlos. Verás. Yo iba a dejar la facultad, ya había decidido que la dejaba, que me iba a Madrid. Un primo mío, Joaquín Vida (que luego ha sido un director importante de teatro y ha hecho varios espectáculos de prestigio), se había ido y se ganaba ya la vida allí. Y yo querría haberme ido también. Entonces mi padre me pidió que intentara un año más seguir con la carrera. Yo le decía, «mira, a mí esto me aburre»; la ciudad se había convertido en algo muy asfixiante; era muy provinciana. Todavía lo es, pero en aquella época mucho más. «Bueno»-me dijo- «yo no voy a impedir que te vayas si tú quieres; pero te pido que te quedes este año». En fin, un año más, si luego iba a conseguir su bendición (que era conseguir su ayuda también), pues podía resistir. Me esperé y ese año ya estaba Juan Carlos [Rodríguez] dando clase en la Universidad. Empezaba a dar clase en la facultad. Creo que era el curso 1970-1971. Y, claro, eso sí. «Esto sí es lo que yo quiero», pensaba. «Estas clases sí me dicen algo, sí me aportan». Y aunque fuera únicamente Juan Carlos, merecía la pena. Yo empiezo a escribir La mala crianza entre 1970 y 1972 (aunque se publicó más tarde, en 1974) coincidiendo con todo eso.

PC: El libro plantea ya una muy respetable lectura histórica. En uno de sus poemas más reconocidos habla, en concreto, de que su generación («los nacidos en los años cincuenta»), ya no son un "producto de posguerra». ¿No consideraban la Guerra Civil como parte de su experiencia? ¿Era la guerra, de alguna forma, ajena a su educación sentimental?

ÁS: Creo que se había establecido ya un corte. Yo tengo hermanos mayores e, incluso, la diferencia de edad con el propio Juan Carlos (que me lleva a mí 7 años) era una diferencia muy notable en valores, en ideología, esa «ideología familiar». No sé cómo decirte... El inconsciente a todos los niveles: en los modos de vida, en relación con las mujeres, los gustos. Cambia todo radicalmente en esos años. La Guerra Civil estaba ahí, claro. Estaba constantemente. Nos dimos cuenta cuando empezamos a entrar en política. Enseguida los padres, los mayores, lo que te ponían por delante, era la guerra. En realidad -y ahora lo pienso-, entonces parecía una enormidad, parecía muy lejano; pero para ellos realmente era nada: habían pasado apenas veinte años. Ellos nos ponían esa barrera y nosotros queríamos pasarla. Es después cuando uno empieza tener conciencia de lo que realmente supuso aquello, ya en la Universidad; 
cuando empiezas a relacionarte y a conocer la obra de Miguel Hernández o de Luis Cernuda; lo qué pasó con Lorca... Es entonces cuando te das cuenta de la verdadera importancia que tiene ese pasado. Sin embargo, con dieciocho o veinte años lo que queríamos era cortar con eso. Para nosotros era «lo viejo» y queríamos otra cosa: otro país con otra imagen, otras preocupaciones. Y eso es muy generacional también.

PC: El libro provocó alguna reacción por parte de su padre.

ÁS: Le molestó un poco el título; como si él fuese el responsable de «la mala crianza». Se lo tomó al principio como una cosa personal. Yo intenté explicarle que no era una cuestión de la peripecia personal, que era una cosa simbólica y generacional, más o menos representativa. Y lo entendió. De hecho, me escribió un poema en el que, a pesar de todo, explicaba que se sentía orgulloso de eso. Realmente, mi padre alentó mucho mi vocación. Él, por una parte, hubiera querido ser médico y, por otra, haber escrito. Las dos cosas le gustaban y seguramente, a lo mejor, podría haberlas hecho si no está la Guerra Civil de por medio. Después, el hecho de tener ya una familia le imposibilitó terminar los estudios de medicina. Las obligaciones familiares, la necesidad de ganar dinero y de mover la casa, recuperar las tierras que habían sido incautadas... En fin, todo eso, le hizo irse por otros derroteros. Lo que intentó siempre fue inculcarnos a nosotros ese gusto por la lectura y por la literatura.

PC: Creo que incluso conoció la poesía de Federico García Lorca gracias a él, un tanto prematuramente para la época.

ÁS: Sí. Él se sabía los poemas de Lorca de memoria en una época en que no circulaban en España. Llegó a tener una edición del Romancero gitano de 1938 que circuló por el frente de la República donde él estaba y que luego se destruyó. Él se sabía poemas de Lorca y de Rubén Darío también. Sabía poemas de Luis Chamizo (que es un poeta regional murciano), poemas de Gabriel y Galán, de Espronceda... Muchos. Y le gustaba mucho recitarlos. Era muy teatral y eso crea un gran atractivo en un niño. Por otro lado, su hermano menor, mi tío Gregorio Salvador, estaba ya trabajando con [Manuel] Alvar. Y, de pronto, la Filología pasó a ser, ya no sólo una cosa bonita y tal, sino algo que también podía dar dinero. Vio que era también un medio de vida y alentó que me dedicara a eso.

PC: Justo al año siguiente, en 1973, entra como Becario de Investigación en la Universidad de Granada y decide casarse. La ruptura generacional y la rebeldía se reflejan también en un matrimonio casi clandestino.

ÁS: Como becario, entré en el 74, pero en el 73 acabé la carrera y me casé. El problema de nuestra boda era que, inevitablemente, si nosotros informamos de nuestra voluntad de casarnos nos hubiéramos metido en un fregado... Era algo que nos horrorizaba 
directamente. Yo luego me he vuelto más flexible. Después no me hubiera importado casarme; quince años después. Pero en aquel momento me horrorizaba. Y a ella, como mujer, más todavía; mucho más. Verás. Su familia era una familia muy aristocrática de Málaga, de mucho dinero y tal. Y aunque son personas liberales, de cara a lo que representaban en la ciudad y tal y cual, pues tendría que haber sido toda una boda. Lo cierto es que pensamos que lo mejor era hacerlo sin que se enterara nadie; así ya estaba hecho y lo tendrían que aceptar. Era, como te digo, algo vital. Queríamos hacer las cosas de otra forma. Realmente queríamos que el mundo fuera de otra manera.

PC: En su siguiente poemario, De la palabra y otras alucinaciones [Publicaciones Arte y Cultura, 1974], vuelve a cambiar de registro y parece abandonar el «beat» para explorar una nueva expresión.

ÁS: Era un texto más «novísimo», por decirlo de alguna manera. Lo que intentaba en ese libro (algo que creo que consigo luego con Las cortezas del fruto) era hacer una reflexión más materialista de la historia poética y del discurso poético. Entonces comienzo a preocuparme de la posibilidad de hacer otro discurso. Un cuestionamiento del discurso tradicional, es decir: «bueno, ¿esto a dónde lleva?, ¿a dónde conduce esto?». Era la sensación de que, al final, acababas haciendo lo mismo. ¿Cómo darle la vuelta a un poema para que salga ese otro discurso que nosotros queremos; un discurso acorde con los tiempos y que, por otra parte, sea revolucionario? Era la ilusión de poder hacer una escritura materialista alguna vez. Ese era nuestro cuerpo teórico, por donde ya nos movíamos. Creo que todo eso ya está ahí y enlaza con Las cortezas del fruto. Si te fijas, mis libros enlazan en cierto modo unos con otros: en La mala crianza hay una vuelta a lo clásico en la última parte que se va desarrollando en De la palabra. Y al final de De la palabra hay todo ese discurso meta-poético que enlaza con Las cortezas del fruto. Entonces va todo como enlazándose. Incluso publiqué como anticipo algunas plaquettes. Alguna parte de Las cortezas del fruto salió adelantada en la antología La poesía más transparente y luego salió otra parte también, me parece que en la revista Antorcha de paja en Córdoba y en Papeles de Son Armadans. Pero ese es un proceso que es más lento y ya muy trabajado.

PC: En medio de todo ese proceso publica usted un libro muy curioso, Los cantos de Ilíberis [Pliegos de Poesía Andaluza, 1976], premiado también en el III Certamen Internacional «El Olivo» para Libros de Poemas.

ÁS: Sí, ese libro es como un paréntesis. De hecho, fíjate, pues lo que ocurre con las mudanzas (o con los divorcios): que se pierden las cosas. En realidad Los cantos de Ilíberis era un cuento. En origen era un cuento que se llamaba... - creo recordar que se llamaba...-, algo así como «El halcón y la flauta». Y es que en los últimos años de carrera leí mucha literatura de la Romania. Teníamos clase con don Andrés Soria (el 
padre de Andrés [Soria Olmedo]), que era un profesor extraordinario. Leíamos a los poetas provenzales, María de Francia y todo eso. Se me quedó un imaginario que me gustó mucho y un verano surgió esa especie de relato. Como relato no sé si funcionaba muy bien, porque era demasiado lírico. El caso es que lo perdí y se me ocurrió irlo deconstruyendo en diferentes textos como un poema épico. En esa época leí también Maniluvios de José Miguel Ullán, que me dio la clave de la forma. También está ahí Ezra Pound (había leído recientemente los Cantos Pisanos); la lírica castellana, la poesía arábigo-andaluza, los mitos de las caballerías o la lírica provenzal. Fue como un bagaje al que quería darle una salida. Un ejercicio realmente. Algo más bien aislado.

PC: ¿Nunca le interesó el orientalismo o aquel bizantinismo tan característicos de la poesía de entonces?

ÁS: No. El orientalismo nunca me ha interesado mucho. Seguramente es un defecto de mi formación, pero no me interesaba. Sobre todo el extremo oriente. Porque sí me interesa el mundo árabe. Me interesa y ha estado presente en otros momentos de mi obra. Pero, hasta ahora, que me han interesado más los haikús y he leído un poco de poesía japonesa, ${ }^{10}$ nunca me ha llamado la atención demasiado.

\section{LA OTRA SENTIMENTALIDAD}

PC: En torno a 1976, empieza ya el periodo de la Transición cuando se asientan las bases de lo que será La otra sentimentalidad. Antonio Jiménez Millán habla de un periodo de grandes expectativas, vivido por todos ustedes muy intensamente; $y$ de los peligros de idealizar hoy toda aquella época. ¿Cómo lo recuerda usted?

ÁS: Por una parte, es lo que él dice: éramos jóvenes y quieras que no... Pero, por otra, fueron también tiempos muy duros, muy sórdidos, según las situaciones y qué casos. Por ejemplo, qué te digo yo..., era muy desagradable que una amiga o una alumna se quedaran embarazadas sin desearlo. Entonces armábamos toda una historia para recolectar dinero entre la gente y que pudiera ir a Londres. Había muchas cosas difíciles y desagradables en aquella época. Las detenciones, los amigos en la cárcel, en fin... También estaban otras cosas más bonitas y los proyectos que conseguíamos sacar adelante.

PC: En el mismo 1976 organizan ustedes aquel homenaje mítico a Federico García Lorca en Fuentevaqueros.

ÁS: Sí, el «Cinco a las cinco». Realmente lo organizó una comisión, la llamada Comisión de los 33, que fue totalmente variopinta, con gente de prácticamente todos

${ }^{10}$ Salvador, A., «Cinco haikús, dos epigramas y un epitafio», La canción del outsider, Madrid, Visor, 2009, pp. 33-40. 
los estamentos sociales (universitario, obrero, profesionales). Todo coordinado por la Junta Democrática y la Plataforma Democrática, que eran las dos grandes organizaciones políticas de entonces. Fue muy emocionante. Y con presencia policial y todo: toda la plaza de Fuentevaqueros rodeada por la Guardia Civil con sus tricornios [ríe]. Teníamos permiso solamente para media hora y el acto estaba totalmente estructurado. Iban a intervenir tales personas en tales momentos y nadie podía salirse del guion. Pero, claro, hubo salidas. Recuerdo que Ladrón de Guevara metió algunas cuñas críticas. Y José Agustín Goytisolo también, que hizo una cosa bastante peligrosa. Le tocaba leer su poema y detrás de él subiría Blas de Otero. Pero cuando estaba ya bajando del escenario, de pronto, volvió a subir - no sé si se dio cuenta o si alguien se lo recordóy pidió el indulto para Puig Antich y otros dos anarquistas que estaban condenados (y que luego los mataron; les dieron garrote). Se creó una situación muy tensa. Hubo un momento de tensión muy fuerte con ese tema y los mandos pensaron suspender el acto. Al final, alguien tuvo buen sentido. Prefirieron dejarlo correr y el acto siguió normalmente. En general, todo allí fue muy emocionante. El pueblo absolutamente lleno de gente...

PC: A ese mismo hilo, también en 1976 nacen otras iniciativas como la Agrupación Antonio Gramsci o el Colectivo 77 (con el que me parece que lanzaron la antología La poesía más transparente) ¿Cómo las recuerda?

ÁS: Yo estuve en la Agrupación (¿cómo se llamaba?... en el organigrama tenía un nombre...) como «libre-oyente». Creo que se llamaba así. No era de número, pero iba como compañero de viaje. Sí. Y luego, posteriormente, el Colectivo 77 que, en realidad, fue antes que la antología. Sí, el Colectivo lo montamos antes. La idea nació aprovechando un poco todo lo que había significado el «Cinco a las cinco». Intentamos hacer un colectivo de acción cultural para que aquello no se quedara parado y pudiera tener una continuidad entre gente que no éramos... bueno, en fin... Quiero decir que la organización del Partido Comunista era entonces muy dogmática, ya que estaba acostumbrada a funcionar así. Y, a pesar de que estaba ya en una línea aperturista, a veces todavía seguía planteando eso de «o conmigo, o lo que está fuera no vale nada». Muchos queríamos ser compañeros de viaje, nos interesaba el momento; pero por una serie de razones no queríamos estar sometidos a su disciplina. Pasaba lo mismo con otra gente próxima a otros partidos, amigos también del PSOE o del movimiento anarquista. Se nos ocurrió entonces hacer ese colectivo de acción cultural. Un punto de encuentro donde pudiéramos apoyarnos gente de los distintos partidos y tendencias, creando conexiones y afinidades unos con otros, pero que fuera independiente. Un colectivo donde no tuviéramos que someternos a la rigidez de un partido.

PC: Todos ustedes eran bastante heterodoxos: tanto los poetas (Javier Egea, Luis García 
Montero y usted mismo), como el profesor Rodríguez...

ÁS: Sí [sonríe]. Juan Carlos estuvo un tiempo en el PCE de una manera más militante; de hecho, él coordinaba la Célula Gramsci. Pero se acabó saliendo. Creo que en 1980. Ya no soportaba más todo aquello. En el Colectivo era un poco distinto. Y como la poesía era lo más fácil de mover, pues lo primero que hicimos fue la antología poética, como dices. ${ }^{11}$ Y también hicimos una antología de prosa: Se nos murió la Traviatta; esa no la conocías.

PC: No; no la conocía.

ÁS: En el año 1978 [ríe]. La publicamos también en Málaga, en la librería El Guadalhorce. Una antología de cuentos y relatos. ${ }^{12} \mathrm{Y}$ también había un equipo de pintores que hicieron exposiciones y tal. Otro de gente de la música. La verdad es que nos invitaban a muchos sitios. Íbamos y leíamos poemas, cantaba la gente... Incluso tuvimos un grupo que se llamaba «La Carreta» con varios cantantes. El equipo musical lo coordinaba Miguel Ángel González que luego ha sido narrador importante y flamencólogo muy reconocido.

PC: Con La otra sentimentalidad también repitieron esas experiencias e hicieron varias tournées poéticas ¿no?

ÁS: Sí, pero eso fue ya de una manera más institucional. Ya en esos años nos llamaban mucho a los institutos; nos llamaban las diputaciones y también para cosas políticas. Nos llamaban, a lo mejor, para que leyéramos poemas durante un mitin en algún pueblo. Era parecido al Colectivo, pero entonces éramos ya menos gente.

PC: Parece que la poesía estaba socialmente muy viva en aquella época.

ÁS: En los setenta y los ochenta, la poesía estaba muy viva. Se movió mucho; mucho.

PC: ¿Qué recuerda de la recuperación de los autores republicanos exiliados? En su libro En el mundo de los mundos [Editorial Traspiés; Granada, 2010] habla de las recuperaciones editoriales de Francisco Ayala, Antonio Machado o Rafael Alberti.

\footnotetext{
${ }^{11}$ «Los versos que a continuación siguen pueden ser un reflejo meridianamente claro de una serie de opciones ideológicas y, a la vez, crítica de las mismas condiciones en las que surgen, de un tiempo y un país; y, en última instancia, parte del discreto encanto de la pequeña burguesía (perdón, don Luis) [...] Partimos de cero hacia la transformación de nuestro propio lenguaje que no es otra cosa que un modo de transformar la realidad en que vivimos [...] Las fórmulas de la Revolución Artística van mucho más allá de las alternativas de partido [...] porque la dialéctica de todo proceso revolucionario que se precie de serlo no tiene ninguna meta, y la vanguardia que representa toda producción artística de cara a la historia, siempre deberá estar ahí presente [...] transparentándose en un proceso en el que la cultura sea por fin un hecho colectivo». AA.VV., «Introductorio rollo y mucha miga». La poesía más transparente, Málaga, Anticuaria El Guadalhorce, 1976, pp. 7-9.
}

${ }^{12}$ AA.VV., Se nos murió la Traviatta, Málaga, Librería Anticuaria El Guadalhorce, 1978. 
ÁS: Del año 1975 a 1977, hubo muchas recuperaciones y reediciones de obras de exiliados. En concreto, yo creo que fue muy importante, muy interesante, la recuperación de Luis Cernuda, porque fue un poeta que nos influyó mucho. A lo mejor no es tan evidente, o no se ha hablado tanto de ella en nuestro caso como, por ejemplo, la de Machado que tiene toda esta teorización sobre la sentimentalidad. Pero, para nuestro discurso poético (como dice Luis «normalizado»), Cernuda fue muy útil. Esa manera de escribir como el habla; una manera directa y reflexiva. Y muy ética. Eso nos influyó mucho. Sobre todo el último Luis Cernuda; al menos, a mí personalmente. ${ }^{13}$ Es esa tradición anglosajona, que luego recoge tan bien Jaime Gil de Biedma. ${ }^{14}$ Aunque no sólo él. A veces se olvidan otros autores del cincuenta que tienen una conexión muy directa con esa tradición como Paco Brines que fue profesor en Oxford, Claudio Rodríguez que estuvo en Cambridge o Ángel [González] en EE.UU...

PC: ¿La Poesía de la experiencia?

Ás: Claro.

PC: Usted colaboró en la edición del importante libro de Robert Langbaum aquí en España con un prólogo.

ÁS: Bueno, en realidad el libro se publicó gracias a mi iniciativa. Y es que era una verdadera barbaridad que hubiera aquí tanta gente hablando de la Poesía de la experiencia y tal, y que no se hubiese traducido. Mucha gente ni lo conocía. No lo habían ni leído. Y eso hay que decirlo. Yo pude leerlo en el ochenta y uno o el ochenta y dos. Un amigo me dio una edición norteamericana. Desde entonces, hubo varios intentos por traducirlo y editarlo, pero no salieron adelante. Y eso hasta el año ¡1996!15

PC: Volviendo un poco a los autores del exilio, entre todas esas figuras que entonces se recuperan y se restauran, parece que la de Rafael Alberti fue fundamental entre todos ustedes,

\footnotetext{
${ }^{13}$ Salvador, A., «La experiencia de Luis Cernuda», Letra pequeña, Sevilla, Editorial Cuadernos del vigía, 2003, pp. 47-60.

${ }^{14}$ «La tradición anglosajona, incluidos los católicos modernos como Eliot, es asumida completamente por Gil de Biedma, desde su misma extracción de clase; y esto último es más importante de lo que parece. Pero es que, además, la lucha contra el franquismo en la que se comprometen amplios sectores de la burguesía española más liberal hace que estos intelectuales - y en concreto Gil de Biedma - establezcan un contacto con las teorías marxistas más evolucionadas (Brecht, Escuela de Frankfurt, Althusser, etc.) cuyos puntos de contacto con el empirismo, en lo que se refiere a la estética, son más que notables». Salvador, A., «Para leer a Jaime Gil de Biedma», Las rosas artificiales, Sevilla, Fundación Genesian, 2002, p. 249.

${ }_{15}$ »Puede ser muy interesante conocer la propuesta de Langbaum acerca de una poesía de la experiencia que no se identifica con un estilo - operación que sí se ha efectuado con demasiada frecuencia en España - sino con lo que podríamos definir como un inconsciente poético mucho más amplio y que, según Langbaum, se desarrolla a lo largo de lo que él mismo llama nuestra tradición moderna». Salvador, A. «The poetry of experience y la poesía española de los últimos quince años». (p. 14) En Langbaum, R., La poesía de la experiencia [Introducción de Julián Jiménez Hefferman], Sevilla, Comares, Colección De Guante Blanco, 1996, p. 14.
} 
su amistad, su presencia, digamos.

Ás: Rafael, bueno, él era muy cariñoso y generoso. La amistad con nosotros nace a partir de su vuelta a España. Me acuerdo del recital que organizó Joaquín Lobato con Arte y Cultura en Vélez-Málaga, donde también participamos. ${ }^{16}$ Joaquín le escribió y Rafael le contestó enseguida, le mandó un dibujo... En fin, él era muy cariñoso con todo el mundo, con toda la gente que le escribía y que iba a verlo. En el año 1980 vino por primera vez aquí, a Granada, a un mitin en defensa de la autonomía andaluza (en defensa de aquel «Artículo 154» para que Andalucía fuese también una autonomía de primera). Dio el mitin en la Plaza de Bibarrambla y ahí lo conocimos levemente. A mí me pidieron que escribiera un artículo de bienvenida para el periódico, que es la «Salutación» que aparecería luego en el Manifiesto Albertista. ${ }^{17}$ Lo conocimos entonces. Estuvimos con él y con Juan Carlos en el Hotel Palace donde se hospedaba y charlamos un rato por la tarde. Aquel día fue una cosa puntual y breve, pero a los dos años volvió a Granada. Tony [Anthony L. Geist] tuvo mucho que ver en eso y él te podrá decir más cosas. En gran parte fue todo gracias a él. Entonces Tony estaba enseñando como profesor en el Darmouth College y tenía un grupo de estudiantes aquí. Tony y yo ya nos conocíamos. Y también conocía a Antonio Sánchez Trigueros, que era el director de la Escuela de Extranjeros de la Universidad de Granada. Por otro lado, también conocía a Rafael y ya tenía una conexión con él, porque lo había llevado a Darmouth. Entonces, un día - como surgen estas cosas - hablando sobre Rafael y tal, Tony nos dice que tiene muchas ganas de volver a Granada (esa cosa suya del reencuentro con Granada); pero no políticamente, sino venir literariamente. Entonces dijimos: «iPues hay que traerlo! Le hacemos un homenaje, un seminario y que venga». Nos coordinamos. Yo dirigía en aquella época el Aula de Poesía de la Universidad y Antonio lo de Extranjeros. Tony hizo la gestión con él y lo trajimos de nuevo a Granada en abril del año 1982.18 Ahí es donde hacemos amistad con él. Estuvo aquí varios días y se sorprendió mucho del ambiente que había, de la inquietud de la gente y de nuestro proyecto. Y ya desde

\footnotetext{
${ }^{16}$ «Con la conferencia pronunciada por el profesor Juan Carlos Rodríguez sobre “La obra de Rafael Alberti y la incidencia de su militancia comunista", y el recital folk por parte de Manuel Guirao han terminado los actos de la VII Reunión de Poesía y I Semana Homenaje a Rafael Alberti. La semana ha transcurrido en general sin incidentes, aunque con bastante tensión por la presencia del Delegado Gubernativo en todos los actos programados, así como una desacostumbrada vigilancia policial en las calles [...] En el recital de poesía estuvieron presentes Francisco Giner de los Ríos, José Luis Cano, Álvaro Salvador, Manuel Salinas, Joaquín Lobato y Antonio Jiménez Millán, entre otros». El País (4 de enero de 1977), s.p.

${ }_{17}$ Salvador, A., «Marineros en tierra», Diario Ideal (24 de febrero de 1980), s.p. Y Egea, J., Salvador, A. y García Montero, L., El manifiesto Albertista. Con una Bienvenida Marinera de Álvaro Salvador y una Despedida Picassiana de Antonio Sánchez Trigueros, Granada, Los Pliegos de Barataria. Editorial Don Quijote, 1982.

${ }_{18}$ «Rafael Alberti, que se encuentra en Granada invitado por la Universidad, ofreció anteanoche un recital de poesía en el Palacio de las Columnas [antigua Facultad de Letras de la Universidad de Granada]. Durante hora y media, el poeta gaditano habló de su gran amigo Federico García Lorca, declamó una selección de sus creaciones más populares e incluso recitó coplas en contra de la Organización del Atlántico Norte». El País (13 de mayo de 1982), s.p.
} 
entonces seguimos en contacto con él. Se puede decir que vino a Granada todos los años, hasta que se casó con esa señora. Hasta 1992, más o menos, venía a Granada todos los años. Unas veces venía institucionalmente; por ejemplo, cuando hicimos un encuentro de poetas andaluces en 1983; ${ }^{19}$ también estuvo en la Tesis Doctoral de Luis; su nombramiento como Doctor Honoris Causa, etc. Otras veces venía sólo a pasar una semana o íbamos nosotros a verlo a Madrid. A todas las cosas que hacía nos invitaba. Me acuerdo del estreno de El hombre deshabitado. ${ }^{20} \mathrm{Y}$ también de un homenaje que le hicieron en Cádiz... ${ }^{21}$ Por lo menos, Javier, Luis y yo íbamos prácticamente a todo.

PC: En el primer número de la revista Letras del Sur hicieron también una recuperación editorial, una actualización, de su literatura republicana y marxista.

ÁS: Sí. En el primer número recuperamos muchos textos de la revista Octubre, que todavía no se habían difundido bien. No sé si Gonzalo Santonja había sacado algo, pero no se conocían en absoluto. Sobre todo su libro De un momento a otro, que para nosotros fue muy importante. ${ }^{22}$ En ese libro Rafael daba, exactamente, el tono que nosotros queríamos para nuestra poesía: una apariencia de cotidianidad de la vida, pero con otros valores. Introduciendo valores diferentes. Es en realidad un libro escrito durante la Guerra, un «poemario de guerra», donde él recuerda su infancia y su formación, cuestionándolos con un tono muy directo, muy amable. Y eso nos interesaba mucho.

PC: Además de la recuperación de Rafael Alberti, en Letras del Sur desarrollaron otros temas muy comprometidos y de mucha actualidad entonces como «Mayo del 68» (No2), otro dedicado a «Andalucía» ( $\left.N^{0} 3 / 4\right)$ y otro dedicado al erotismo en literatura ( $\left.N^{\circ} 5 / 6\right)$, algunos de los pilares que asientan el proyecto de La otra sentimentalidad.

ÁS: Queríamos que esa revista fuese una revista cultural, pero también de actualidad, de cosas que preocupaban. Todos los que señalas eran temas que interesaban en aquel

${ }_{19}$ «Los poetas Vicente Aleixandre, Rafael Alberti y, en general, los componentes de la Generación del 27, así como la poetisa Elena Martín Vivaldi, serán homenajeados en el Encuentro de poetas andaluces que promueve la Consejería de Cultura del Gobierno andaluz en colaboración con el Ayuntamiento, la Universidad y la Diputación de Granada [...] La comisión organizadora está compuesta por los escritores andaluces José G. Ladrón de Guevara, Juan de Loxa, Javier Egea, José Heredia Maya, Luis García Montero, José Gutiérrez, Rafael Juárez y Álvaro Salvador». El País (20 de abril de 1983), s.p.

${ }^{20}$ Centro Cultural de la Villa de Madrid (actual Teatro «Fernando Fernán Gómez»). 18 de octubre de 1988. Dirección: Emilio Hernández. Música: Carmelo Bernaola. Intérpretes: José María Rodero, Antonio Dechent, Ramón Madaula, Aitana Sánchez-Gijón y Nancho Novo.

${ }^{21}$ «Rafael Alberti recibe el homenaje de los jóvenes poetas andaluces y de la Bahía de Cádiz [...] Ante la presencia del propio Alberti el grupo de poetas integrado por Antonio Jiménez Millán, Álvaro Salvador, Juvenal Soto, Javier Egea, Juan José Téllez, Luis García Montero, Jesús Fernández Palacios y Antonio Enrique, en nombre de sus compañeros de la joven poesía andaluza, tratarán de hacer patente su deseo de que el Premio de las letras hispanas Miguel de Cervantes le sea concedido al poeta gaditano». El País (2 de julio de 1983), s.p.

${ }^{22}$ Alberti, R., De un momento a otro (Poesía e Historia 1932-1937), Madrid, Ediciones Europa-América, 1937. 
momento y estaban entre las inquietudes de la gente. Que se aprueba la constitución, pues entonces tratamos aspectos de la República. Con el movimiento de los estudiantes y de la Universidad, pues «Mayo del 68» (que además era el aniversario). Y luego el andalucismo y Andalucía, sí.

PC: Ustedes reivindicaron el andalucismo desde muy temprano. Pienso, por ejemplo, en el manifiesto Canción del Sur de 1969;23 o aquel congreso al que asistió en Minnesota sobre la «Las Nacionalidades del Estado Español». ${ }^{24}$ ¿Cómo lo valora desde hoy?

ÁS: En aquella época entendíamos un poco todo aquello en el sentido NacionalPopular que le daba Antonio Gramsci a esos problemas. ${ }^{25}$ Se trataba de reivindicar unas señas de identidad y de construir una «cultura popular», pero auténtica. Sin embargo, salvo casos muy puntuales como el de Carlos Cano - que tuvo que hacer un esfuerzo titánico en muchos momentos y pelearse con unos y con otros-, no lo conseguimos. Era una cosa muy complicada. Digamos que la «cultura oficial» no revisó nunca en ningún momento esos planteamientos folcloristas o popularistas, sino todo lo contrario. Los alentó. Los alentó mucho. Incluso el PSOE en un momento dado, para desactivar el andalucismo propiamente político, intentó absorberlo alimentando la tradición folclórica, defendiendo las ferias y esas cosas (la imagen más tópica y estereotipada de Andalucía). Eso, finalmente, diluyó la posible «cultura popular» auténtica hasta convertirla en algo inoperante. Pienso que nos dimos cuenta de que considerarnos así, algo más «nacionales», pues era un trabajo un poco absurdo; un poco inútil.

PC: En el año 1980 llega la publicación de uno de sus libros más importantes: Las cortezas del fruto [Editorial Ayuso; Madrid, 1980] texto que incorpora el prólogo mítico «La guarida inútil» del profesor Juan Carlos Rodríguez y con el que se inaugura, de hecho, La otra sentimentalidad.

ÁS: Sí. Había un concepto que Juan Carlos repetía siempre; que se repetía constantemente al hablar de la Literatura Contemporánea y de lo que nosotros queríamos hacer: tenía que ser algo otro. Algo que se situara en otra perspectiva, en otra situación. De ahí vino lo de «otra sentimentalidad». En toda la primera parte - un

\footnotetext{
${ }^{23}$ «Juan de Loxa alentó el Manifiesto Canción del Sur cuyos componentes (Carlos Cano, Antonio Mata, Ángel Luis Luque, Enrique Moratalla) reclamaban una evolución de la llamada canción flamenca para ponerla al servicio de nuestro pueblo como expresión de su particular proyección humana». Soria Olmedo, A., Literatura en Granada. Poesía (1898-1998), Granada, Diputación de Granada, 2000, p. 87.

${ }^{24}$ «Las nacionalidades del Estado español: una problemática cultural ha sido el título del simposio organizado por el Departamento de Español y Portugués de la Universidad de Minnesota (Estados Unidos) durante los días 24 y 25 de este mes con el fin de plantear en el mundo académico norteamericano la situación de la cultura catalana, vasca, gallega y andaluza dentro de los programas de estudio y la formación de hispanistas en Literatura Peninsular [...] Álvaro Salvador, poeta y profesor de Literatura de la Universidad de Granada fue el representante de Andalucía». El País (27 de mayo de 1984), s.p.
}

${ }^{25}$ Gramsci, A., Literatura y vida nacional, México, Juan Pablos Editor, 1976. 
poco teorética; un poco teórica - de ese libro, lo que yo intento es desarrollar esa idea de Lenin cuando señala que es necesario abrir, descortezar el fruto hasta llegar a la semilla. ${ }^{26}$ Después, una vez planteada la cuestión teórica primero, pues voy ya a la escritura, a la práctica. Y este ejercicio es necesario: escribir unos poemas con los que el lector se identifique y que lleguen a emocionar. Por eso los poemas finales se entienden como el resultado de las reflexiones teóricas previas.

PC: En uno de sus poemas más famosos, "La Gaya Ciencia», habla de la poesía como algo completamente ajeno a la voluntad del autor y de sus intenciones...

ÁS: En el momento en que se escribe el texto, ya tiene vida propia. Tiene personalidad y habla por él mismo en función del propio contexto que lo acompaña. Se independiza, por decirlo así, y ya no tiene una relación de necesidad con el autor. Esa es una idea marxista. La plantearon más recientemente François Lyotard y Jean Baudrillard, entre otros. Y también los «recepcionistas» como Paul Leman y toda esa gente. Es también la idea de Borges en «Pierre Menard, autor del Quijote»: un poema dice hoy unas cosas y dentro de cincuenta años dirá otras. Como te digo, Las cortezas es el libro mío más teórico quizá. El más reflexivo y meta-poético. El poema «La Gaya Ciencia» es de hecho una poética. En su momento fue escrito intentando descubrirle un poco el truco a los Novísimos. La idea era descubrir el artificio, decir: «esto es prestidigitación y aquí está el truco» [sonríe]. Desenmascarar. Si te fijas, el poema comienza sin decir nada, realmente; hasta que acaba diciendo lo fuerte.

PC: «...inútiles y mágicas palabras...»

ÁS: Sí, «...supuestamente mágicas, en realidad trucadas».

PC: Usted practica y reivindica ahí el vanguardismo y también la idea de compromiso

\footnotetext{
${ }^{26}$ Abriendo la lectura del poemario Las cortezas del fruto (introduciendo el prólogo de Juan Carlos Rodríguez «La guarida inútil») Álvaro Salvador sitúa la siguiente reflexión: «Sin embargo, había que comprender, descubrir, preservar, descortezar, depurar ese fondo...». La cita forma parte de los cuadernos de trabajo de Lenin escritos durante el transcurso de la Gran Guerra europea y se enmarca ampliamente en la revisión del programa social-demócrata de la Segunda Internacional. Entre otros estudios que van desde los clásicos Heráclito y Demócrito, pasando por los revolucionarios burgueses ilustrados, hasta las obras mismas de Carlos Marx y Federico Engels, el líder soviético dedica ahí una gran atención al estudio del legado intelectual de Hegel (su lógica, su dialéctica y su concepción de la historia), con el objetivo de eliminar las sucesivas envolturas metafísicas de su filosofía y llegar hasta el núcleo materialista de su teoría sobre «el ser». La referencia de Álvaro Salvador ilumina, en concreto, el método de «descortezamiento» o épluchage - progresión científica del análisis de la ideología-con el que Lenin critica las deformaciones mecánicas o simplificaciones idealistas de la metodología dialéctica, señalando: «Movimiento y AUTO-movimiento (movimiento autónomo, espontáneo, interiormente necesario), cambio, movimiento y vitalidad, principio de todo auto-movimiento, impulso del movimiento y la actividad - opuesto al SER MUERTO - , ¿quién creería que esto es la médula del hegelianismo, del hegelianismo abstracto y abstrusen (pesado, absurdo)? Esta médula había que descubrirla, comprenderla (hinüberretten), desentrañarla, depurarla que es precisamente lo que hicieron Marx y Engels». V.I. Lenin, Obras completas. Tomo XLII. Cuadernos filosóficos, Madrid, Akal. Ediciones de Cultura Popular, 1987, p. 136.
} 
histórico y «poesía útil», ¿fue difícil llegar a asociarlos en la práctica poética?

ÁS: Sí, lo fue. Verás. La enseñanza de Juan Carlos es que la escisión en la que se mueve la ideología burguesa entre lo racional y lo irracional, lo trascendente y lo formal, es precisamente lo que hay que superar. Eso es lo que hay que romper. Ha sido una de las cuestiones por las cuales yo no he estado muy de acuerdo con la radicalización posterior de Luis. Y hemos tenido muchas discusiones; aunque siempre ha prevalecido la amistad, claro. Porque, si planteas que no te interesa el vanguardismo, no lo estás superando. Estás, en realidad, optando por uno de «los dos» y te mueves dentro de esa misma problemática. Te estás posicionando, digamos, en uno u otro sentido. Estás yendo de un sitio a otro. Y no; no es eso. Yo pienso que no hay porqué desterrar los procedimientos vanguardistas. ¿Por qué? Me parece que ahí Luis cayó en una confusión. Y no sólo él, por supuesto. También otros muchos. Otros amigos como Felipe Benítez [Reyes], [Vicente] Gallego... muchos. En mi opinión, una poesía experimental no tiene porqué ser necesariamente hermética o ininteligible. Y ahí, creo yo, es donde ellos se equivocan cuando dicen: «La superchería del irracionalismo» y tal. No tiene por qué ser necesariamente así. Hay que intentar, eso sí, que la poesía experimental no sea mala poesía. Pero no hay porqué renunciar a esos procedimientos o a esas estrategias. «Capital de la gloria», ese texto de Rafael [Alberti], con toda esa emocionalidad de tipo surreal, llega y causa un impacto enorme en el lector. Y no tiene porqué entenderse racionalmente, con exactitud lógica, lo que se le está diciendo. Tiene que emocionar todo ese golpe de imágenes. ${ }^{27}$ Creo que es también lo que intenta hacer Javier en Raro de luna. ${ }^{28}$ Es la «tradición de la ruptura», como nos decía Octavio Paz. ${ }^{29}$ La última tradición que tenemos. Pero es tradición. La Vanguardia ya es también «La Tradición».

\section{PC: ¿Considera esa «tradición de la ruptura» un paso post-moderno?}

ÁS: Si entendemos la Post-Modernidad en el sentido en que la entiende Frederic Jameson, yo creo que sí. La Post-Modernidad como el resultado cultural del capitalismo avanzado. ${ }^{30}$ Pero eso no quiere decir que sea el final de nada. Ni mucho menos. Es,

\footnotetext{
27 «Ciudad de los más turbios siniestros provocados / de la angustia nocturna que ordena hundirse al miedo / en los sótanos lívidos con ojos desvelados, / yo quisiera furiosa, pero impasiblemente, / arrancarme la voz, pero no puedo [...] Los árboles acodan, desprovistos, las ramas / por bardas y tapiales / donde con ojos fijos espían las troneras / un cielo temeroso de explosiones y de llamas». Alberti, R., «Capital de la gloria». De un momento a otro (Poesía e Historia 1932-1937), Barcelona, PPU, 1993, p. 69.

${ }^{28}$ Egea, J., Raro de luna [prólogo de Antonio Jiménez Millán. Ilustraciones de Rafael Alberti], Madrid, Hiperión, 1990.

${ }^{29} \mathrm{Paz}, \mathrm{O}$. , «La tradición de la ruptura». Obras completas. La casa de la presencia. (Poesía e Historia), Madrid, Galaxia Gutenberg / Círculo de Lectores, 1999, p. 132.

30 «Toda postura ante la postmodernidad en la cultura - se trate de una apología o de una condenatambién es, a la vez y necesariamente, una toma de postura implícita o explícitamente política ante la naturaleza del actual capitalismo multinacional. [...] Precisamente por esto, me parece esencial concebir
} 
sencillamente, un momento; un momento ensimismado o solipsista. Este es un momento en el que se reflexiona irónicamente, se vuelve sobre el pasado... que es la posición de Umberto Eco y, en cierto modo, de otros como Vattimo. Sin embargo, yo lo veo más como Jameson. Estamos en un momento; un momento histórico. Pero eso no quiere decir que mañana todo esto no sea ya otra cosa y que no cambie. De hecho, ahora con esta crisis se está volviendo y regresando sobre los discursos utópicos, los discursos rupturistas. ¿Por qué? Pues porque la situación históricamente lo requiere.

PC: Todos ustedes exploran también el erotismo, que parece que tiene un papel muy importante en su poética, incluso también en la más comprometida.

ÁS: En eso hay mucho de Freud y de Lacan. Y de Althusser, claro. Los leíamos y los estudiábamos mucho en ese tiempo. La incorporación del psicoanálisis a la poesía... Lo que intentábamos con La otra sentimentalidad era precisamente la defensa de unos valores que fueran distintos a los valores tradicionales. La defensa de la libertad en todos los sentidos; cambiar la vida; cambiar la estructura familiar; re-estructurar «el cuerpo» (poético) - que es otra idea de Juan Carlos; algo que en aquel momento se veía muy lejano, pero me parece que hoy ya no lo está tanto-; la importancia de la intimidad y las relaciones interpersonales que queríamos vivirlas de otra manera, de una manera muy distinta. La idea era no volver otra vez a las dualidades burguesas: «esto en frente de lo otro», y tal. Es lo que se llama ahora la transversalidad (entonces no existía ningún concepto parecido). Era irse a otro lugar, ver desde otra perspectiva. Intentaba ser un concepto dialéctico y progresivo. Precisamente eso: ir un paso más allá. Situarnos en otro lugar porque, precisamente, ese paso se había dado.

\section{PC: ¿Cotidianizar el compromiso?}

Ás: Claro.

PC: Post-Modernidad, erotismo y «compromiso cotidiano» se asocian también en su libro Tristia [Editorial Rusadir; Melilla, 1982], escrito junto con Luis García Montero. Es un libro muy sorprendente por la intensidad de su sintonia; de hecho, si no se consultan las antologías posteriores donde usted y Luis García Montero, digamos, reclaman ya sus respectivos poemas, resulta muy difícil poder diferenciar en la lectura los textos escritos por uno u otro. ¿Cómo fue su proceso de composición?

la postmodernidad no como un estilo, sino, más bien, como una dominante cultural: perspectiva que permite la presencia y coexistencia de un abanico de rasgos muy diferentes aunque subordinados unos a otros [...] desde el hermetismo y el material explícitamente sexual, hasta la crudeza psicológica y las abiertas expresiones de desafío social y político que superan todo lo que hubiera cabido pensar en los momentos más extremos del modernismo. Y no sólo se reciben con una enorme complacencia, sino que estos mismos rasgos se han institucionalizado y armonizan con la cultura oficial o pública de la sociedad occidental». Jameson, F., Postmodernidad o la lógica cultural del capitalismo avanzado, Barcelona, Paidós, 2011, pp. 14 y 17. 
ÁS: Sí. Verás. Hay algunos trucos en ese libro. La idea surgió mientras Luis estaba preparando un libro que se iba a llamar Diario de un poeta recién cansado, como el que luego publicó Juaristi (y es que nos hizo mucha gracia que apareciera con el mismo título que había pensado Luis). En aquella época yo estaba escribiendo también los «Poemas de Italia», como los llamo yo. Yo fui a Italia por primera vez en el año 1979. Había viajado ya a Francia y a otros lugares, pero Italia me causó una impresión tremenda. Me dejó muy impactado (sobre todo Florencia). Además, me impactó mucho también por cierta simbología e imaginería urbanas que se parecen mucho a Granada: los cipreses, los jardines, los paseos. Intenté explorar esa conexión y -al releer y recordar- se me vino toda esa tradición... Por eso el poema a Andrea Navagero y a Juan Boscán: «el caminante que regresa», que era un poema al exiliado también (de hecho, en alguna antología que me pidieron para Alberti di ese poema). Entonces, bueno, vimos que los poemas se parecían mucho. Se parecían en el tono y, más o menos, lo que estaban diciendo. Y era lógico, porque en esos años estábamos todo el día hablando y discutiendo. Se nos ocurrió unirlos. Esa idea que te decía de hacer cosas nuevas: «Venga, unimos los poemas e intentamos publicarlos. Los mandamos a un premio o algo, y a ver qué pasa». Y nos pusimos a trabajar. Cada uno tenía esbozos de poemas sin acabar o poemas que estaban atrancados, y los pusimos en común. Nos ayudamos el uno al otro a acabarlos. Y discutíamos mucho. Por ejemplo, la imagen del cobrador - esa que tiene Javier en Paseo de los Tristes,$-{ }^{31}$ esa imagen de el inesperado mensajero que llega, la estuvimos discutiendo esos días a ver cómo lo metíamos ahí. A ver a quién le salía mejor. Al final, salió ese poema de Tristia: «abre, quizás será el cartero y te traerá noticias». ${ }^{32} \mathrm{Y}$ hay muchos poemas que están publicados, bien como suyos o como míos, pero en que los finales son realmente del otro. Algunos - los menos - están hechos completamente entre los dos. En realidad, la mayoría están completados o ajustados. En el Premio [Ciudad de Melilla; Accésit 1981] nadie se imaginaba que era de dos autores. Era nuestra idea en ese momento: eliminar las distancias entre las poéticas y que pudieran ser poemas intercambiables. Creo que lo conseguimos durante un tiempo en esos años. Salvando las distancias entre todos, también el poema «Paseo de los Tristes» ${ }^{33}$ se parece mucho a «Sonata triste por la luna de Granada» de El jardín extranjero; ${ }^{34}$ al «Suena una música» mío. ${ }^{35}$ Es decir, hay versos que son iguales prácticamente: «eran tiempos difíciles...»y tal.

\footnotetext{
${ }_{31}$ «Aquí habita el dolor: / ese salvaje cobrador diario / que llega, empuja, nos derriba / y queda». Egea, J., Paseo de los tristes, Madrid, Point de Lunette, 2007, p. 14.

${ }^{32}$ Montero, Álvaro [Álvaro Salvador y Luis García Montero], «Poema de las posibilidades», Tristia, Melilla, Rusadir, 1982, p. 79.

${ }^{33}$ Egea, J., «Paseo de los tristes». Paseo de los tristes. Madrid, Point de Lunette, 2007. p.89.

${ }^{34}$ García Montero, L., «Sonata triste para la luna de Granada», El jardín extranjero, en Poesías completas. Madrid, Galaxia Gutenberg / Círculo de Lectores, 1997, p. 80.

${ }^{35}$ Salvador, A., «Suena una música», El agua de noviembre, Granada, Maillot Amarillo, 1985, pp. 49-56.
} 
PC: Desde un punto de vista histórico, es curioso que lanzaran los manifiestos y la antología de La otra sentimentalidad después de haber publicado todos estos libros, tan potentes además, donde ya la poética «otra» estaba plenamente en marcha y consolidada. Amparo Amorós ha aventurado la posibilidad de una estrategia, una estrategia editorial. ${ }^{36}$ Pienso que, tal vez, pudo ser parecido a lo que hizo Carlos Barral con el realismo crítico y el Grupo del Cincuenta...

ÁS: No, no, no. Vamos a ver. Lógicamente a nosotros nos interesaba tener una repercusión, pero en realidad nuestra posición ya estaba hecha. Yo - que era algo mayor - era una persona considerada ya en los círculos poéticos. Ya tenía mi nombre. Luis había ganado el Premio Adonais que en aquel momento era un premio muy importante (y con la repercusión tremenda que tuvo). ${ }^{37}$ Javier había ganado el Premio Juan Ramón Jiménez, ${ }^{38}$ con críticas extraordinarias de Aurora de Albornoz, de Félix Grande... No, no. Teníamos ya una posición. A nosotros lo que nos interesaba en realidad, lo que queríamos, era que se conocieran nuestras ideas, nuestra poética, digamos, militante. Pensábamos que nuestra obligación era, no sólo escribir de una determinada manera, sino también defender esa manera de escribir. Que se entendiera porqué y llegase a la mayor gente posible. Por eso nos decidimos a hacer la antología. ${ }^{39}$ Además -no estoy muy seguro...-, no lo recuerdo bien, pero creo que fue algo que no salió exactamente de nosotros. Creo que la idea salió del profesor Antonio Sánchez Trigueros que era quien dirigía la colección de Los Pliegos de Barataria, donde se publicó la antología. Como el año anterior cuando vino Rafael habíamos publicado el Manifiesto Albertista, creo que Antonio nos lo propuso. Nos dijo: «Ahora que estáis tan en el candelero, ¿por qué no publicamos una antología vuestra?» y tal. A nosotros nos gustó la idea y le dijimos: «De acuerdo, una antología; pero con un manifiesto también»; que, en definitiva, eran los artículos que habíamos publicado unos meses antes en la prensa. Y lo hicimos de esa manera. Y Javier... Bueno, Javier como siempre se negó: "Yo no voy a escribir un manifiesto», decía. "Yo mejor escribo un poema», que se tradujo en esa poética tremenda en verso. ${ }^{40} \mathrm{El}$ caso es que nos reunimos varios días en mi casa. Incluso, te diría que, aparte de la teoría y todo eso - que estaba muy presente - , aparte de toda nuestra conceptualización teórica, me parece que el término «otra sentimentalidad» nos lo dio mi exmujer, Margarita Caffarena. Hablando de Machado, las teorías de Juan Carlos, la «nueva sentimentalidad» y todos los textos que

\footnotetext{
${ }^{36}$ Amorós, A., «iLos Novísimos y cierra España! Reflexión crítica sobre algunos fenómenos estéticos que configuran la poesía de los años ochenta», Ínsula 512-513. (1989), pp. 63-67.

${ }^{37}$ García Montero, L., El jardín extranjero, Madrid, Adonais, 1983.

${ }^{38}$ Egea, J., Paseo de los Tristes, Huelva, Instituto de Estudios Onubenses, 1982.

${ }^{39}$ Egea, J., García Montero, L. y Salvador, A., La otra sentimentalidad, Granada, Pliegos de Barataria, 1983.

40 «Porque a pesar de todo nos hicimos amigos / y me mantengo firme gracias a ti, poesía, / pequeño pueblo en armas contra la soledad». Egea, J., «Poética», La otra sentimentalidad, Granada, Pliegos de Barataria. Editorial Don Quijote, 1983, p. 25.
} 
manejábamos entonces como antecedentes, creo que fue ella la que en un momento dado dijo: «Pues otra: otra sentimentalidad». Lo pensamos mucho y después de darle vueltas así se quedó.

PC: Hay en particular una idea que se repite tanto en sus manifiestos de entonces (y también en la antología 1917 versos de Benjamín Prado), ${ }^{41}$ que es la ternura: la "ternura como forma de rebeldía», «enfrentarse al mundo con mucha ternura», ser "tiernamente subversivos»... ¿Por qué ese sentimiento en particular; ese concepto?

ÁS: Pues intentando huir de la violencia crítica. La crítica es necesaria y está muy bien. Pero suele ser violenta y agresiva. Suele ser muy descalificadora. A nosotros no nos interesaba o, mejor dicho, no nos parecía ético - y mucho menos en un discurso poético - «hacer violencia», sino hacer algo tierno. Aunque haya crítica, aunque se critique lo que debe ser criticado, hay que hacerlo siempre con ironía, con sonrisa. Siempre con una justificación y una comprensión de lo criticado. Esa era la idea de «la ternura». Creo que es algo que está ya muy presente en los autores del cincuenta; sobre todo en los poetas del cincuenta. Y no sólo en los españoles; también en los hispanoamericanos como Mario Benedetti o Ernesto Cardenal. Esa era la idea.

PC: No es un concepto muy fácil de encontrar en la teoría literaria...

Ás: No. No lo es, claro. Sobre todo en la Literatura Contemporánea. Tal vez por eso, creo yo, las lectoras femeninas, las mujeres, se han identificado mucho con nuestra literatura. Porque ellas son más proclives a eso: a perdonar y a justificar, en cierto modo. Bueno, también te digo que eso no significa no ser inflexible con las cosas que hay que serlo. Pero no la descalificación violenta, la descalificación agresiva o dogmática. Queríamos huir de eso. En realidad, no siempre se ha cumplido esa actitud. Ni siquiera entre nosotros. Porque es muy difícil.

PC: A partir del año 1983, se ha dicho que la cohesión del grupo se deshace y comienzan caminos diferentes y más personales, ya todo diluido en el gran movimiento de «la experiencia».

Ás: Bueno. Juan Carlos, creo yo, exagera un poco en eso. Fue más tarde. Realmente, fue más tarde. El año en que comienza la cosa a resquebrajarse, cuando ya empieza a manifestarse una sintomatología, es a partir de 1987. Hay, por un lado, una circunstancia física, digamos, y es que yo me voy un curso a EE.UU., al Darmouth College, y ya hay una distancia. Por otra parte, se produce entonces el nombramiento de Luis como Vicedecano. Eran los años de los movimientos estudiantiles - los últimos grandes movimientos estudiantiles - con la Reforma Universitaria, que fue tremenda. ${ }^{42}$ Hubo mucho lío y Luis estuvo muy preocupado con todo aquello; muy

\footnotetext{
${ }^{41}$ AA.VV., 1917 versos [prólogo y edición de Benjamín Prado], Madrid, Vanguardia Obrera S.A., 1987.

${ }^{42}$ Ministerio de Educación y Ciencia. Real Decreto 1496/1987, de 6 de noviembre, sobre obtención.
} 
preocupado. Y Javier también empieza entonces a darle vueltas a su proyecto de Raro de luna que le llevó mucho tiempo. Hubo, en fin, una primera desconexión que se fue transformando en distancia a partir de ahí. Nosotros siempre nos enseñábamos todo antes de que se publicara y desde entonces pues ya no. Al volver de EE.UU., por ejemplo, me encuentro Diario cómplice (del que apenas había leído varios poemas). Hay ya como otros intereses en cada uno. Seguíamos, claro, con la amistad. Pero aquella primera sintonía tan intensa ya no, ya no se daba.

PC: ¿Cree que, tal vez, la situación política y social tuvo algo que ver? Quiero decir si quizá les influyó o afectó algo la decepción de las esperanzas de la izquierda, el «desencanto» y toda aquella relajación de los movimientos politicos populares que hubo después del 23-F. ¿Qué opina?

ÁS: No creo. No. Yo creo que no. Las esperanzas que la izquierda tenía (que no sé si eran buenas o exageradas; porque eso habría que verlo), al menos las esperanzas que nosotros teníamos como izquierda, se diluyen realmente después, con la política socialdemócrata. El golpe de estado fue un golpe de atención en relación a las autonomías. Eso lo analiza muy bien Manuel Vázquez Montalbán. Lo que él llamaba el «pacto del capó». Aquel pacto que se firma encima de un coche en la puerta del Congreso entre el general Armada y los líderes de los partidos políticos, cuando dijeron que el golpe se acabaría y los militares obedecerían el mandato de la democracia, siempre que el Estado de las Autonomías no fuera hacia un estado de tipo federal y no hubiera desarrollo autonómico. Y así sucedió. Se quedó ahí, parado. Y otras libertades también. Otras libertades que se prometía que iban a ser mucho más rápidas y que hasta el gobierno Zapatero pues no se desarrollaron apenas. Fue entonces cuando se empezó a practicar ese tipo de política. Y luego fue la OTAN. Y luego la reconversión industrial... muchas cosas. Hubo muchos palos a la clase trabajadora.

PC: ¿Cómo valora aquel «Estado Cultural», así llamado, al que aspiraban los primeros gobiernos socialistas? ${ }^{43}$

ÁS: Bueno, en ese sentido, sí. Sí hubo un esfuerzo institucional importante hacia la cultura que tuvo efectos positivos. Por ejemplo, las diputaciones en Andalucía se preocuparon mucho por mover la cultura. Y no sólo en las ciudades, que podía ser algo más elitista. Por decirte lo más próximo a nosotros: pues crear aquí el Museo de

expedición y homologación de títulos universitarios.

${ }^{43}$ «El PSOE tratará de articular una nueva estructura cultural del Estado y desplegará una intensa labor legislativa. Hoy comienza el traspaso de poderes del Ministerio de Cultura saliente al Partido Socialista. Este ya tiene diseñada su política cultural. El área de la cultura, descuidada por los gobiernos de la UCD, va a ser una clave para la identidad del futuro gobierno, ya que si éste no tiene mucho campo de actuación propia en otras áreas, en cambio en la de la cultura sí cuenta con terreno abierto para iniciativas y cambios». El País (10 de noviembre, 1982), s.p. 
Arte Contemporáneo «José Guerrero», magnífico; o financiar la revista Olvidos de Granada o la Colección Maillot Amarillo - que ha sido tan importante-, la Colección Genil y otras colecciones de libros locales; salas de exposiciones... Mucha actividad. Y también la creación del Centro Andaluz de las Letras que creaba un circuito por toda Andalucía para llevar a los escritores a que leyeran sus poemas a los pueblos, a los institutos - todo aquel circuito de la enseñanza media. Y la presencia de los escritores en la universidad. Y las becas que se dieron durante bastante tiempo a la creación literaria... En fin, mucho. Mucho y yo creo que bien, en términos generales. Lo que pasa es que, a la vez, también se cometieron excesos y se hicieron muchos gastos, a veces, inútiles o superfluos. Esa fue la parte mala.

PC: En el año 1986 se edita, apoyado por la Universidad y la Diputación de Granada, el impresionante número monográfico de la revista Olvidos de Granada, que recogía los trabajos de un congreso dedicado a la Generación del Cincuenta. Un grupo de escritores al que ustedes no sólo reconocen como maestros y amigos, sino al que también restauran históricamente.

ÁS: Sí, Palabras para un tiempo de silencio. Al congreso que celebramos aquí (y que se llamó igual: «Palabras para un tiempo de silencio») vinieron todos. Todos estuvieron entonces en Granada. En muchos casos, eran autores que - por distintos motivoshabían sido rechazados por los Novísimos. Ellos estaban legitimando una evolución estética que daba la espalda a la historia y a la situación del país; por eso censuraban a sus «hermanos mayores» (que eran los que les habían enseñado a escribir). Eso a nosotros nos molestaba bastante. ¿Cómo podían decir que Ángel González era un poeta pedestre? No, hombre. Y luego, además, también molestó que inmediatamente después de producirse la Transición ellos eran los más rojos y los que habían estado ahí. Y enseguida cogiendo el carné del PSOE. Eso molestaba, porque cuando vivía Franco estaban de un veneciano que te caías. Y no quiero ser injusto con ellos tampoco. Tanto Luis como yo, y otra gente de nuestra generación, hemos mantenido una relación bastante cordial con algunos Novísimos como Siles o Carnero. Incluso hay algunos de ellos, como José María Álvarez, cuya obra poética a mí me ha interesado mucho. En fin, nosotros lo que queríamos era defender nuestra poética frente a aquellos que intentaban continuar con la línea estética «decadente». Aquel fue un acto de reivindicación. Reivindicación de esos poetas y novelistas que eran extraordinarios, con una gran sabiduría y que estaban siendo muy maltratados. ${ }^{44}$ Incluso - fíjate-

${ }_{44}$ «En nuestra opinión, los caprichosos movimientos de las modas y maneras literarias pueden haber abonado entre nosotros una cierta disposición maniquea que estaría desechando como inútil o simplemente out lo que no reúne las dos o tres características de superficie que pide una determinada manera de entender la modernidad. En nombre de, por ejemplo, el cosmopolitismo, la modernización o el neo-individualismo, fácilmente se puede acabar en una ignorancia de la propia historia que convierta al cosmopolitismo en papanatismo aldeano, a la modernización en encantamiento para ignorantes y al neo-individualismo en coartada para deslizar, otra vez las mismas aburridas cuitas personales o de grupo». AA.VV., «Invitación» en AA.VV., Palabras para un tiempo de silencio, Revista Olvidos de Granada, 
también la popularización de Jaime Gil de Biedma que se produjo en torno a esos mismos años. Realmente, hasta la publicación de Las personas del verbo, Jaime era un poeta relativamente poco conocido. ${ }^{45} \mathrm{Y}$ no muy apreciado. Se consideraba que no tenía «vuelo»: vuelo poético. Una poesía inteligente, una buena poesía, pero que no tenía esos excesos de lenguaje que era lo que entonces se apreciaba más. Entonces, coincidiendo con la publicación de su obra en una editorial, además, de mucha difusión como Barral (y coincidiendo con ese cambio de sensibilidad que se está produciendo alrededor de la recuperación de Luis Cernuda), en el año 1977 Jaime da una conferencia en Sevilla y se convierte de la noche a la mañana en el poeta más admirado por los jóvenes. En algún momento poco antes de morir —en el año 1988 o 1989-, llegó a decir en alguna entrevista que le hicieron que estaba ya harto de tanta popularidad: «Sí, hablan de mí» decía. «Hablan, ¡pero no me leen!» [ríe]. Decía: «¡Coño, parezco una estrella de cine!». $Y$ es que Jaime era... era inexorable. Era tremendo. Él era muy buena persona, pero muy intolerante con la falta de inteligencia. Eso no lo toleraba nada. Nada. A veces se ponía muy desagradable con esas cosas y llegaba a ser muy cruel incluso.

PC: En torno a esas mismas fechas publica usted su libro El agua de Noviembre [Maillot Amarillo, 1985], con el que parece alcanzar ya su voz más personal, más auténtica y más madura, con todo ese impresionante análisis intimo y sentimental, y con una presencia muy destacada de la memoria como modo de enfrentarlo y asegurarlo. ¿Cómo llegó a esa poética?

ÁS: Bueno, puedo decirte que en esa época yo me divorcié. Me estaba separando de mi primera mujer. Es un libro que se corresponde con un momento de ruptura, tanto de ruptura poética como de ruptura personal. Por un lado, he llegado a una poética que estaba buscando desde hacía tiempo; y, por otro, era el fin de un proyecto que había construido junto a otra persona. Ahí se abre otra perspectiva. También hubo una cosa casi fisiológica, que era la frontera de los treinta años; cuando, de pronto, te crees que te has hecho viejo... En fin, todas esas cosas. Todo se reúne en un momento dado y está ahí. La memoria es el intento de la reconstrucción; la reconstrucción de la subjetividad para afrontar la nueva etapa, para seguir adelante.

PC: Su poesía siempre fue muy urbana, pero particularmente en El agua de Noviembre parece que la ciudad se convierte en testigo e, incluso, también en protagonista de su historia intima (la memoria y el espacio perdido; el «destierro»). Usted es, de hecho, uno de los poetas de su generación que más ha escrito sobre la ciudad «moderna». ${ }^{46}$ Incluso, en muchos de sus poemas, hace referencias explícitas a los pisos donde ha vivido (pienso, por ejemplo, en el terrible

\footnotetext{
número especial (1985), p. 9.

${ }^{45}$ Gil de Biedma, J., Las personas del verbo, Barcelona, Barral Editores, 1975.

${ }^{46}$ Salvador, A., El impuro amor de las ciudades (Notas acerca de la literatura modernista y el espacio urbano), La Habana, Casa de las Américas, 2002.
} 
«Callejón de la Isla» de Ahora todavía). ${ }^{47}$

ÁS: Eso es puramente La otra sentimentalidad. Javier, Luis y yo estamos en eso. La ciudad representa una de las preocupaciones nuestras más importantes. La ruptura con el pasado «viejo» y rural, la configuración de otra España que esperábamos que fuera otra cosa. No la España del pasado, sino una España moderna. Son los años ochenta; los años de lo urbano (La movida en Madrid, y todo aquello). Y nosotros consideramos que nuestra poesía no sólo tenía que ser urbana, sino que tenía que mostrarlo. Tenía que demostrarlo. La ciudad es la geografía moderna de los sentimientos (esa idea de la que habla Javier). Es un viaje que tiene que ver con la infancia: desde el paraíso de «los cármenes» donde yo crecí, hasta la ciudad moderna y la urbe. Es la destrucción de la ciudad entendida como un símbolo. En Granada se produjo el ensanche en los años cincuenta y sesenta. Granada era una ciudad que estaba muy bien trazada y diseñada, pero la especulación se saltó todo ese trazo y se hicieron muchas barbaridades. La dinámica de la ciudad se destruye y, así, en cierto modo, también se pierde la ciudad misma. Y luego está la peripecia personal. Verás. Yo vivía hasta ese momento -como profesor casado y con familia- en la parte más moderna de la ciudad. Sin embargo, ese sentimiento de reconstrucción, de recuperación que expresa el libro me hace regresar, volver a vivir, a residir en la ciudad antigua. El «Callejón de la Isla» fue el domicilio último que tuve en el Albaicín. Me mudé en esa época, en el año 1984, y estuve diecisiete años viviendo allí. Estaba justo en frente de la Alhambra; no en la perspectiva más próxima, sino un poco más alto (abría la ventana de mi balcón y era entonces el mejor cuadro de la casa [sonríe]). Pienso que también es un símbolo del conflicto generacional, de la despreocupación de los jóvenes... Está señalado intencionadamente, por ejemplo, en el poema «Los territorios perdidos» de Ahora todavía. ${ }^{48}$ No sé, la verdad, si soy justo o injusto. La globalización, en fin. Es un tema que se repite mucho. Ahora, he escrito otro poema que es recurrente con ese tema; con la ciudad y los muchachos. Es un poema de mi último libro; un poema ecologista, preguntándome si a los muchachos que están ahí envenenándose con el botellón, si les importará que cada vez haya menos hidrógeno en el planeta, que se estén destruyendo las plantas, que estén desapareciendo las especies... Es una cuestión, una pregunta. Todo el poema es un gran interrogante. ${ }^{49}$ Bueno, ¿qué hora es? A ver... Yo creo que me voy a tomar un vino. ¿A ti te apetece tomar algo?

PC: Yo tomaré una caña Álvaro; muchas gracias.

\footnotetext{
${ }^{47}$ Salvador, A., «Callejón de la Isla», Ahora, todavía, Sevilla, Renacimiento, 2001, pp. 13-14.

48 «Aquí estuvo mi infancia [...] estuvo mi vida [...] Hoy, / estos muchachos que comparten / una felicidad ruidosa, / que beben y que escupen / y rompen las botellas / contra los muros de mi casa, / no pueden sospechar / la memoria escondida / en sus noches en vela, / qué territorios guardan». Salvador, A., «Los territorios perdidos», Ahora, todavía, Sevilla, Renacimiento, 2001, pp. 22-25.

${ }^{49}$ Salvador, A., «La sustancia del tiempo», Fumando con mis muertos, Sevilla, Vandalia, 2016, p. 13.
} 


\section{ENTRE-SIGLOS}

PC: Una vez se disuelve el movimiento de La otra sentimentalidad y da paso al más amplio de la Poesía de la experiencia, una de las discusiones más polémicas, más controvertidas, fue el debate sobre «la normalización», que usted asocia con la consolidación y estabilización de las clases medias en el país y la «crisis de las ideologías».

ÁS: Yo discutí bastante con Luis sobre eso. Sí. Especialmente el concepto de «normalización». Yo me manifesté contra la «normalización» porque me parecía un concepto peligroso. No se puede hablar de «normalización» cuando, por ejemplo, todavía están persiguiendo a tus amigos que son homosexuales. ¿Cómo hablamos de «normalización»? ¿De qué estamos hablando? Pienso que desde nuestra formación psicoanalítica no se puede defender ese concepto. Yo entiendo lo que Luis quiere decir, claro. Sé lo que eso significa: nuestro intento por producir un discurso que cualquier persona pueda leer sin pensar que es una cosa esotérica o sólo para unos cuantos iniciados. Sin embargo, hay mucha gente que no lo entiende bien o no entiende esa idea apropiadamente. Está bastante relacionado, creo yo, con una «cultura de la socialdemocracia», fácilmente asimilable y blanda. $\mathrm{Y}$ eso no es lo que perseguimos. Nuestra primera intención era mover las conciencias. Y, de hecho, si lees la poesía de Luis, pues sigue siendo una poesía fuerte; una poesía que remueve e interroga la conciencia pequeño-burguesa. Entonces, me parece contradictorio. Me pregunto, ¿de qué «normalización» estábamos hablando? Tenemos que ser rigurosos usando el lenguaje y usando los conceptos. En la Poesía de la experiencia hubo una especie de maridaje artificial, pienso yo (y eso sí que fue un marketing). Se utilizó como una especie de marbete - que si García Martín ${ }^{50}$; que si García Posada ${ }^{51}$ - , un cajón de sastre. Y ahí entró todo. Algunos, incluso, se han ido luego por otros derroteros como, por ejemplo, los valencianos - Vicente [Gallego] o Carlos Marzal - con esa cosa mística o neo-mística. Se han abierto líneas diferentes. En realidad, éramos así desde el principio, con diferencias y peculiaridades. Tengo un artículo en el que hablo un poco de eso. ${ }^{52}$

\footnotetext{
${ }^{50}$ García Martín, J.L., Treinta años de poesía española (1965-1995), Sevilla, Renacimiento / La veleta, 1996.

${ }^{51}$ García Posada, M., La nueva poesía (1975-1992), Madrid, Crítica, 1996.

52 «Quizá el problema esté en la confusión que ha creado la confluencia de varias tendencias, con sus tradiciones diferentes y sus posiciones ideológicas muy distantes entre sí, en lo que se ha dado en llamar la Poesía de la experiencia. [...] La una es heredera de lo que podríamos llamar la moral estética tradicional: el mundo del arte es autosuficiente y sólo a través de sí mismo se justifica como realidad. Es incluso una realidad más coherente que la realidad real pues sus reglas y normas permiten las construcción y la contemplación de un mundo ordenado y perfecto [...] La otra línea parte de la necesidad de normalización a través de los procedimientos de la experiencia de la escritura y de la lectura, pero con el convencimiento de que, aunque el divorcio entre la realidad y la construcción del poema sea un hecho insalvable, la poesía es un artefacto socialmente útil. Esa línea arranca en la llamada otra sentimentalidad». Salvador, A., «La experiencia de la poesía», Letra Pequeña, Granada, Cuadernos del Vigía, 2003, pp. 227-236.
} 
PC: En su línea «otra» de la Poesía de la experiencia, parece que en su obra han ido tomando cada vez más importancia algunos procedimientos distintivos como la ironía o el subrayado de ese carácter artificial o ficcional del rito poético, muy intensamente destacados en sus libros La condición de personaje [La General, 1992] (pienso en poemas como el divertido «El hombre de moda» ${ }^{53}$ o en «Siesta» $\left.{ }^{54}\right)$ y Ahora todavía [Renacimiento, 2001].

ÁS: Por un lado, «El hombre de moda» es un poema dedicado especialmente a Juan Carlos Rodríguez y a Luis [sonríe]. Cada uno en una generación. Sí, porque ellos son los profesores fascinantes. Ese tipo de profesor que llega y enamora con lo que dice, con su porte y con sus maneras. Son muy seductores. Y es, un poco, un homenaje a ellos; a esa posición que tienen de teatralidad y a ese drama que, sin embargo, también llevan dentro y que no se ve. Y, por otro lado - claro-, «Siesta», que es el poema que yo considero mi segunda poética: «La Gaya ciencia» primero y luego «Siesta». Si te das cuenta, señala un momento en el que yo ya empiezo a dudar (lo que me parece bastante sano, por otra parte). A dudar de la eficacia de lo que estamos haciendo. Dudar no solo de la poesía en general, que no es sino algo ambiguo (ambiguo como la literatura y como el arte en general), sino a dudar incluso también de lo nuestro, de nuestros planteamientos de La otra sentimentalidad. Y es algo que se recrudece en mis libros posteriores.

PC: Ahora, todavía, en particular, se publica tras un largo silencio. Un libro que aparece «inmerso en las sombras ya desde el inicio», como dice el profesor Juan Carlos Rodríguez, con un tono radicalmente lúcido y bastante escéptico.

ÁS: Sí, ese es el texto de Juan Carlos «Escrito bajo una lámpara».55 Fue la presentación que él hizo del libro antes de publicarlo. Hicimos una lectura en el Museo de la Casa de los Tiros, en una habitación que se llama La Cuadra Dorada; es una habitación muy bonita que ha sido el lugar de nuestras lecturas en los últimos veinte años. Verás. Allí se reunía la primera Academia de Granada que se creó en el siglo XVI: la Academia de los Granada-Venegas (que eran descendientes de antiguos nobles árabes que se habían cristianizado). Se reunían allí muchos escritores: vinieron Góngora, Lope de Vega, Soto de Rojas que estaba aquí; en fin, una serie de escritores. Y, bueno, ahí hicimos una lectura de inéditos del libro mío con una introducción de Juan Carlos, que preparó ese artículo. También creo que lo hizo con algún libro de Luis; con La intimidad de la serpiente o Completamente viernes. ${ }^{56} \mathrm{Y}$ otro artículo que escribió para

\footnotetext{
${ }^{53}$ Salvador, A., «El hombre de moda», La condición de personaje, Granada, La general, 1992, pp. 44-45.

${ }^{54}$ Salvador, A., «Siesta», La condición de personaje, Granada, La general, 1992, pp. 19-20.

${ }^{55}$ Rodríguez, J.C., «Escrito bajo una lámpara», Dichos y escritos (Sobre «La otra sentimentalidad» y otros textos fechados de poética), Madrid, Hiperión, 1999, pp. 142-148.

${ }^{56}$ Rodríguez, J.C., «Según sentencia del tiempo. Según la curva del espacio (A propósito de la poesía de Luis García Montero)», Dichos y escritos (Sobre «La otra sentimentalidad» y otros textos fechados de poética),
} 
completar la presentación de Troppo Mare de Javier, que hicimos a través del Aula de Poesía de la Universidad que dirigía yo, en el Palacio de la Madraza; una especie de conmemoración de la primera publicación de Troppo Mare. ${ }^{57}$ En fin, lo que yo quiero decir ahí, en muchos poemas, es que esa «mentira» que nosotros reivindicábamos y que, efectivamente, es una «mentira», que es un hermoso artificio, puede no ser ético. Incluso sin que uno lo perciba. Es decir, se te escapa de las manos; la poesía tiene esa vida propia de la que hablábamos y puede en algún caso no ser ética o no tener la ética que uno pretende. Entonces es como un tiro que sale por la culata: te estás pegando el tiro tú mismo.

PC: ¿Cree que a Javier Egea la poesía se le pudo escapar de las manos? En algún testimonio se ha comentado que se dejó llevar por algunos derroteros auto-destructivos...

ÁS: Sí, eso es cierto. A ver. Javier empezó a beber muy pronto, con quince años o así. Yo creo que se hizo adicto muy joven. Él iba mucho con la generación anterior a la nuestra. Se movía con gente mayor como los Rafael Guillén, los Guevara... Toda esa generación mayor, que eran muy tabernarios. Y un chaval de quince años, si además tiene propensión al alcohol, pues se alcoholiza. Y él se alcoholizó. Es como el tabaco. Los que hemos estado enganchados sabemos que lo que hay que hacer es no volver a probarlo. Y eso, a pesar de que cuando no bebía - los periodos de «dique seco» - fue cuando escribió sus libros, cuando tenía mayor productividad. Sin embargo, no se toleraba a sí mismo sin beber. Tal vez, el alcohol era consecuencia de otros problemas psicológicos que no se había tratado. Se trató, finalmente, con psicoanálisis. Aunque yo no sé tampoco cómo se hizo el psicoanálisis o cómo era el psicoanalista. «¡Ya me he curado!», decía. «¡Ya está! Lo que me pasa es que estaba enamorado de mi madre». ¡Pues para eso no hacía falta gastarse el dineral que se había gastado, ni todo este viaje! Claro, no se había curado de nada. No le sirvió de nada. Era algo más difícil. Y muy personal. Una de las últimas veces que nos vimos (una vez que vino Pere Rovira a una lectura y que estuvimos en un bar, poco antes de..., en fin, poco antes de matarse), comentaba que no iba a intentar quitarse nunca más del alcohol. «Sé que no puedo», decía. Yo le respondía: «Bueno, Javier, lo que tienes que intentar es quitarte del todo y no eso de ahora bebo y ahora no bebo. No: del todo». Me llegó a decir que tenía miedo de que un día lo encontraran muerto en una cuneta. Eso a mí me alarmó. Me preocupó mucho. Se lo comenté también a Luis y recuerdo que lo estuvimos hablando. $Y$, sin embargo, en esa misma época, parecía que se sentía bien: se compró un coche (él siempre tuvo una motillo y nunca le había gustado conducir); tenía muchos proyectos

Madrid, Hiperión, 1999, pp. 178-184.

${ }^{57}$ Rodríguez, J.C., «Como si os contara una historia», Dichos y escritos (Sobre «La otra sentimentalidad» y otros textos fechados de poética), Madrid, Hiperión, 1999, pp. 151-156. 
de viajes; estaba con su libro de los sonetos. ${ }^{58}$ No parecía..., en fin. Es cierto que a él le afectó mucho la caída del muro. Era mucho más militante que nosotros, más radical y aquello le desanimó mucho. También le desanimó la poca acogida que tuvo su libro Raro de luna. Y, tal vez, fue un error publicarlo. Un error, al menos, publicarlo en aquel momento.

PC: Hay quien utiliza la muerte de Javier Egea contra ustedes. También, incluso, desde la izquierda.

ÁS: Sí. Algunos patateros comunistas utilizan su muerte. La están utilizando fundamentalmente contra Luis.

PC: Usted, particularmente, ha tenido alguna polémica reciente a ese respecto con motivo de la edición de su Poesía Completa y esos controvertidos fragmentos extractados de sus diarios..$^{59}$

ÁS: Es que hay que saber cómo era Javier. Esas cosas que escribió en su diario son cosas que él decía cuando se enfadaba; pero eso no tiene nada que ver con el aprecio que él nos tuviese. Él se mató en julio de 1999. En diciembre de 1998 yo hice mi oposición a cátedra y él estuvo todos los días allí conmigo, apoyándome. Quiero decir que la relación no tenía ninguna fisura como amistad. A él le hubiera gustado tener un poco más de repercusión. Le hubiera gustado culminar su proyecto de una poesía materialista. ${ }^{60}$ Claro, uno siempre se marca unas utopías como meta, como objetivo poético o vital. Sin embargo, hay que ser lo suficientemente inteligente como para saber que la luna no la vas a coger; que la luna no se coge. No se coge nunca. Ese exceso fue lo que a él lo perdió. Yo creo que no sabía calcular bien. Él era un tipo de poeta que lo echaba todo; ponía siempre todo en cada verso. Todo lo ponía al límite. Y esa

\footnotetext{
${ }^{58}$ Egea, J., Sonetos del diente de oro. Granada, Asociación para la Investigación y Crítica de la Ideología Literaria en España (I\&CILE), 2006.

${ }^{59}$ Para seguir la polémica completa pueden consultarse los siguientes textos: [1] Egea, J., Poesía completa [prólogo de Manuel Rico y edición de José Luis Alcántara y Juan Antonio Hernández García], Madrid, Bartleby y Fundación Domingo Malagón, 2001, p. 59. [2] Salvador, A., «Olor a espera», Granada hoy (24 de abril de 2011), s.p. [3] Rico, M., «Álvaro Salvador y la Poesía Completa de Javier Egea: mi discrepancia», Culturamas (28 de abril de 2011), s.p. [4] Salvador, A., «Otras puntualizaciones a Manuel Rico», Al margen (6 de mayo de 2011), s.p.

${ }^{60}$ «¿Qué es materialismo? fue una pregunta tan fuerte para Javier Egea como para el romántico Gustavo Adolfo Bécquer aquel ¿Qué es poesía? [...] Es una pregunta tan extrema que no tiene respuesta, al menos no tiene respuesta clara, porque el poeta Javier Egea, como el poeta Gustavo Adolfo Bécquer, contesta de forma metafórica: Materialismo eres tú. [...] Tal vez convenga sacar nuestro amor a la plaza pública. Tal vez nuestro amor se convierta así en el espacio de las preguntas, de la reflexión y el encuentro. Se trataría de construir otro tipo de relaciones que no se basen en la explotación. Hoy, en medio de un mercado mundo cada vez más salvaje, todo aquel esfuerzo puede resultar baldío y lejano. Aunque sólo han pasado 20 años». Mora, A., "Qué es materialismo», en Egea, J., Contra la soledad, Barcelona, DVD, 2002, pp. 161-163.
} 
es su mayor grandeza. ${ }^{61}$ Alguna vez he pensado en escribir algo sobre ello, pero no se puede; no se puede todavía. Hay un verso de Rosario Castellanos que dice que, «el que se mata, mata lo que ama». ${ }^{62}$ La faena mayor que hizo fue matarse, que es, además, lo más anti-materialista y lo más anti-marxista. Pero, ¿hay cosa más burguesa que esa? ¿Hay algo más derrotista y más decadente? Se venció. Se venció y, al vencerse él, dio por supuesto que todo el mundo estaba vencido. Todo lo que habíamos intentado. Todos nosotros. Fue un golpe durísimo. Para nosotros y para todos los amigos: Antonio [Jiménez Millán], Ángeles [Mora], Mariano [Maresca] que era muy amigo de Javier... Fue un golpe muy duro para todos. Luis ha hecho hace poco una novela autobiográfica en la que no habla casi sobre Javier. Ha preferido no hablar. No podemos. No se puede todavía.

PC: En Granada existe una larga tradición de suicidios, ¿no es así?

ÁS: Sí, en Granada han sido varios. El poeta Pablo de Águila, uno. José Ignacio Moreno Olmedo, que era también muy amigo nuestro, se mató al poco tiempo de Javier: se tiró al tren; llevaba muchos años perdido, drogado - había sido heroinómano - y era un tipo muy inteligente, compañero nuestro del Departamento. Y también se tiró al tren Miguel del Pino (al que Javier le dedicó una de las partes de Troppo Mare). ${ }^{63}$ Hay una tradición maldita en Granada: el agua y la sangre... Verás. Yo hice una guía literaria de Granada...

PC: Sí, la conozco. He venido precisamente leyéndola en el viaje desde León... ${ }^{64}$

ÁS: ... pues La Alhambra misma es un libro de poemas. Todas las paredes están llenas, no sólo de salutaciones, sino de auténticos poemas. Son poetas como Ibn Zamrak o Ibn al-Jatib. Estos visires poetas murieron asesinados por sus enemigos políticos. Y es ahí donde empieza ya esa leyenda negra. También la rebelión de los moriscos. Y luego los masones; Granada fue la cuna de la masonería española en la época de

${ }^{61}$ «Javier Egea no quiso nunca que su vida se limitase a un ejercicio de seducción con el que suplir carencias naturales. Supo trascender esas carencias -al menos durante un tiempo y a duras penas- hacia la solidaridad con el resto de los sufrientes, sufrientes de amor o de injusticia social. Y esa solidaridad también quiso y supo ejercerla a través del bálsamo, del consuelo que elaboraba al elaborar su poesía y ponerla al servicio de cientos de lectores. Esos cientos de lectores que se sentían solidarios con el dolor del poeta, encerrados con sus libros en las solitarias horas de la madrugada, o compartiendo alcohol en los bares y tabernas abiertos a las altas horas de la noche para los solitarios. Y, por fin, en las manifestaciones colectivas y públicas del dolor, en los mítines y manifestaciones de los desposeídos de la tierra, con los que siempre se identificó Javier». Salvador, A., «Otro romanticismo», en Geist, A., y Salvador, A. (eds.), Cartografía poética. 54 poetas españoles escriben sobre un poema preferido, Sevilla, Renacimiento, 2004, p. 173.

${ }^{62}$ Castellanos, R., «Privilegio de la suicida», Poesía no eres tú, México, Fondo de Cultura Económica, 1995, p. 107.

${ }^{63}$ Egea, J., «El viajero I, II y III», Troppo Mare, Granada, Dauro, 2000, pp. 53-62.

64 Salvador. A., Guía literaria de la ciudad de Granada (Itinerarios árabe y renacentista), Granada, Lavela, 2007. 
Fernando VII (aquí se refugia el Gran Oriente español). Al duque de Campo Verde lo destierran de Madrid y se viene aquí. Desde aquí se preparan todos los golpes contra Fernando VII; por ejemplo, el de Torrijos. Lo de Mariana Pineda es sólo la punta del iceberg de toda esa conspiración liberal. Y Lorca, por supuesto. En fin... Toda esa tradición pesa mucho. $Y$ es que Granada es una ciudad un poco intoxicante en ese sentido. En el sentido de la sobredosis de belleza, de lirismo. Es una ciudad de la que te tienes que separar de vez en cuando. De pronto, cuando pasa un tiempo - al menos yo- necesito irme unos meses fuera y distanciarme.

PC: Usted ha viajado mucho a EE.UU. Ya ha escrito que es un país que le atrae. ${ }^{65}$ Sus visitas parecen haber dejado incluso huellas muy notables en algunos de los poemas de su libro La canción del outsider [Premio Ciudad de Melilla. Visor, 2009]. ${ }^{66}$

ÁS: He estado bastantes veces en Estados Unidos y siempre han sido periodos muy agradables. Iba a ir a Delaware hace poco, pero era para dar clases de conversación y tal. Y así ya no me merece la pena. Si me voy ya es de una manera más cómoda. De entre todas, la de Seattle ha sido la mejor estancia. Tengo varios poemas dedicados a esa visita y dedicados a Seattle. Exceptuando los «Poemas de Italia» de Tristia (espera... y también el de «Los tejados de Praga» que aparece en Ahora, todavía), ${ }^{67}$ pues nunca había escrito sobre mis viajes. La de Seattle fue una estancia extraordinaria - estuvimos en la gloria - y allí sentí de nuevo la necesidad de escribir.

PC: Ya se ha escrito que su último libro, Fumando con mis muertos [Vandalia, 2016], largamente esperado -compuesto durante siete años-constituye un notorio homenaje a algunos de sus referentes poéticos de fondo ${ }^{68}$ ¿Podría ser considerado en ese sentido la reivindicación de una poética?

Ás: Bueno, no era esa mi intención al escribirlo. Lo que ocurre es que cuando se escribe un libro de madurez - que no se sabe muy bien si será el último - es inevitable que surjan todos los referentes que uno tiene y que los homenajee. ¿Reivindicación de una poética? Sí, seguramente. Cada libro que escribimos es una reivindicación de

65 «En primer lugar, los amigos, gente encantadora que nos ha tratado de maravilla, como hermanos de toda la vida; en segundo lugar las condiciones de trabajo (jay, las bibliotecas estadounidenses!); en tercer lugar la ciudadanía: esa sensación tan agradable de que los profesionales van a intentar hacer bien las cosas, con una sonrisa en la cara y con la satisfacción de ser eficaces, o de que la gente va a ser amable porque les compensa más ser amables que desagradables [...] La ciudadanía, sí, ese principio ilustrado básico de la civilización occidental que sólo he podido experimentar prácticamente en las ciudades estadounidenses y en unos cuantos, pocos, países europeos». Salvador, A., «El regreso», En el mundo de los mundos, Granada, Traspiés, 2010, p. 137.

${ }^{66}$ «El muelle de Mathews Beach», «La balada de Sam Murao» y «Nocturno de Nueva Inglaterra», Salvador, A., La canción del outsider, Madrid, Visor, 2009, pp. 22, 24 y 78.

${ }^{67}$ Salvador, A., «Los tejados de Praga», Ahora, todavía, Sevilla, Renacimiento, 2001, p. 26.

${ }^{68}$ Jiménez Millán, A., «Fumando con mis muertos de Álvaro Salvador», Infolibre (15 de abril, 2016), s.p. 
nosotros mismos, de nuestra vida y de nuestra escritura.

PC: Fumando con mis muertos se caracteriza por una gran coherencia con respecto al completo de su obra previa; siendo, a la vez, también un libro sorprendente y en muchos sentidos arriesgado. Parece acentuar, en esa línea, una combinación -suya característica- entre la reflexión moral y afectiva, la ironía crítica y provocadora e inusitadas perspectivas urbanas y esquemas de vanguardia (pienso en poemas como «Contra-usura»o «Ciudad negra»).

ÁS: Siempre me ha gustado el riesgo, no sólo en literatura sino en todos los órdenes de la vida. Hay algunos libros míos - pocos - que no parecen tan arriesgados; pero quizá el riesgo consistía en eso, precisamente; en que no parecieran arriesgados. Siempre me interesó la neo-vanguardia. En realidad, la mayoría de mis libros no se parecen mucho formalmente. Escribí «Ciudad negra» como resultado de uno de los cabreos que me produjo mi ciudad. Granada, que es una ciudad bellísima y muy poética, es también bastante decepcionante desde el punto de vista humano. En cierto modo, utilicé como modelo la poesía expresionista de los años treinta (Trakl, Brecht y los poetas alemanes de esa época), pero intercalando resonancias lorquianas y mitos relativos a mi ciudad. «Contra-usura» nació de la necesidad de manifestarme contra el robo que estaba perpretando la banca española contra los ciudadanos; y, al mismo tiempo, de advertir del peligro de que esa situación - tal y como nos ha enseñado la historia - derivara en totalitarismo.

PC: Para finalizar me atrevo a preguntarle si, en este aparatoso y convulso fin-de-siglo, confia usted todavía en que la poesía pueda llegar a ser todavía un artefacto útil. Hasta dónde cree que puede llegar hoy ese individuo consciente, intimamente comprometido con la historia (y con su «propia historia») que prefiguraba La otra sentimentalidad y que nos propone en sus versos.

ÁS: Creo que la poesía volverá a ser lo que ha sido siempre desde Homero, aunque ahora atraviese una seria crisis. Ese fenómeno de cantautores, youtubers y tuiteros está banalizando la poesía y es posible que tanto su consideración como su valor se vean seriamente dañados. Por otro lado, de ese individuo sí que descreo hoy. ¿A dónde puede llegar...? ¿A académico de la Lengua o a pegarse un tiro en la sien con una escopeta? Algunas trayectorias de personas a las que uno quería y en las que uno creía desaniman. 


\section{BIBLIOGRAFÍA}

AA.VV., Degeneración del 70. Antología de poetas heterodoxos andaluces, Córdoba, Antorcha de Paja, 1976.

AA.VV., La poesía más transparente, Málaga, Librería Anticuaria El Guadalhorce, 1976. AA.VV., Se nos murió la Traviatta, Málaga, Librería Anticuaria El Guadalhorce, 1978.

AA.VV., Antología consultada de la nueva poesía andaluza (1963-1978), Manuel Urbano (ed.), Sevilla, Aldebarán, 1980.

AA.VV., «Palabras para un tiempo de silencio», Revista Olvidos de Granada, Número especial, 1985.

AA.VV., 1917 versos, Benjamín Prado (ed. y not.), Madrid, Vanguardia Obrera S.A., 1987.

ALBERTI, R., De un momento a otro (Poesía e Historia, 1932-1937), Barcelona, Editorial PPU, 1993.

AMORÓS, A., «¿Los Novísimos y cierra España! Reflexión crítica sobre algunos fenómenos estéticos que configuran la poesía de los años ochenta», Ínsula 512513 (1989), pp. 63-67.

CASTELlANOS, R., Poesía no eres tú, México, Fondo de Cultura Económica, 1995.

DÍAZ DE CASTRO, F., Vidas pensadas. Poetas en el fin de siglo, Sevilla, Renacimiento, 2002.

(ed.), La otra sentimentalidad. Estudio y antología, Sevilla, Vandalia, Fundación José Manuel Lara, 2003.

, «La condición de personaje», La Manzana Poética. Revista de Literatura, Creación, Estudios Literarios y Crítica, 31 (Junio 2012), pp. 43-50.

DÍAZ DE LA GUARDIA, F., Los Ángeles: una leyenda del pop español, Granada, Ramalama, 2006.

EL PAÍS (archivo web). Disponible en https://elpais.com/archivo/ [consultado 1510-2017]

EGEA, J., Troppo Mare, Granada, Dauro. 2000. , Contra la soledad, Barcelona, DVD. 2002.

, Argentina 78, Granada, Fundación de Investigaciones Marxistas y La Tertulia Ediciones. 2003.

, Paseo de los tristes, Sevilla, Point de Lunette. 2010.

, Poesía completa I [prólogo de Manuel Rico], Madrid, Bartleby, 2011.

- Poesía completa II. Obra dispersa e inédita, Madrid, Bartleby, 2012.

, Taller del autor (1969-1999), Volumen I, Madrid, Bartleby, 2015.

EGEA, J., SALVADOR, A., GARCÍA MONTERO, L., Y SÁNCHEZ TRIGUEROS, A., El manifiesto Albertista. Con una Bienvenida Marinera de Álvaro Salvador y una 
Despedida Picassiana de Antonio Sánchez Trigueros, Granada, Pliegos de Barataria, 1982.

EGEA, J., SALVADOR, A. y GARCÍA MONTERO, L., La otra sentimentalidad, Granada, Pliegos de Barataria, 1983.

GARCÍA MARTÍN, J.L., Treinta años de poesía española (1965-1995), Sevilla, Renacimiento / La veleta, 1996.

GARCÍA MONTERO, L., Poesía: cuartel de invierno, Madrid, Hiperión, 1988. , Confesiones poéticas, Granada, Maillot Amarillo, 1993. , Poesía (1983-2005), Barcelona, Círculo de Lectores / Galaxia Gutemberg 2006.

GARCÍA MONTERO, L., y MUÑOZ MOLINA, A., ¿Por qué no es útil la literatura? Madrid, Hiperión, 1993.

GARCÍA POSADA, M., La nueva poesía (1975-1992), Madrid, Crítica, 1996.

GEIST, A. L., «Suena una música por los callejones de la poesía de la experiencia». La Manzana Poética. Revista de Literatura, Creación, Estudios Literarios y Crítica, 31 (Junio, 2012), pp. 51-56.

GEIST, A. L., y MONLEÓN, J. B. [eds.] Modernism and Its Margins. Reinscribing Cultural Modernity from Spain and Latin America, New York, Garland Publishing, 1999.

GIL DE BIEDMA, J., Las personas del verbo, Barcelona, Barral Editores, 1975.

GRAMSCI, A., Literatura y vida nacional, México, Juan Pablos Editor, 1976.

GUZMÁN SIMÓN, F., Granada y la revolución 70. Poetas y poéticas de la revista "Poesía 70», Granada, Comares, 2010.

, De «Tragaluz» a «Letras del Sur»: panorama de las revistas universitarias de la Transición en Granada (1968-1978), Granada, Universidad de Granada, 2011.

HOBSBAUM, E., Revolucionarios, Barcelona, Editorial Crítica, 2003, p. 331.

JAMESON, F., Postmodernidad o la lógica cultural del capitalismo avanzado, Barcelona, Paidós, 2011.

JIMÉNEZ MILLÁN, A., «Fumando con mis muertos de Álvaro Salvador», Infolibre (15 de abril, 2016), s.p.

LANGBAUM, R., La poesía de la experiencia. El monólogo dramático en la en la tradición literaria moderna, Granada, Comares, 1996.

LENIN, V.I., Obras completas. Tomo XLII. Cuadernos filosóficos, Madrid, Akal y Ediciones de Cultura Popular, 1987.

LÓPEZ SALINAS, A., La Alianza de las Fuerzas del Trabajo y la Cultura, Madrid, Forma Ediciones, 1977.

PAZ, O., Obras completas. La casa de la presencia. (Poesía e Historia), Madrid, Círculo de Lectores / Galaxia Gutenberg, 1999.

RICO, M., "Álvaro Salvador y la Poesía Completa de Javier Egea: mi discrepancia», Culturamas (28 de abril de 2011), s.p. 
RODRÍGUEZ, J.C., Teoría e historia de la producción ideológica. Las primeras literaturas burguesas. Siglo XVI, Madrid, Akal, 1974.

, «La guarida inútil», prólogo en SALVADOR, A., Las cortezas del fruto. Madrid, Endimión, 1980.

,Dichos y escritos. Sobre "La otra sentimentalidad" y otros textos fechados de poética, Madrid, Hiperión, 1999.

, La norma literaria, Barcelona, Debate, 2001.

La literatura del pobre, Granada, Comares, 2001.

ROMANO, M., «Las inclemencias del tiempo: sobre Ahora, todavía de Álvaro Salvador», Siglo XXI, literatura y cultura españolas. Revista de la Cátedra Miguel Delibes, 5 (2007), pp. 251-262.

, Revoluciones diminutas. La otra sentimentalidad en Álvaro Salvador y Javier Egea, Sevilla, Renacimiento, 2012.

SALVADOR, Á., Y... Granada, Universidad de Granada, 1971.

- De la palabra y otras alucinaciones, Málaga, Publicaciones Arte y Cultura Plaza del Carmen, 1974.

, Los cantos de Iliberis, Jaén, Pliegos de Poesía andaluza «El Olivo», 1976.

, «Las cortezas del fruto», Papeles de Son Armadans, CCXXXIX, 1976, pp. 145-155).

, La mala crianza, Málaga, Librería Anticuaria El Guadalhorce, 1978.

, Las cortezas del fruto, Madrid, Endimión, 1980.

, Trisita [en colaboración con Luis García Montero], Melilla, Rusadir, 1982.

, El agua de noviembre, Granada, Maillot Amarillo, 1985.

, Estación de servicio, Valencia, Editorial Estación, 1989.

- La condición de personaje, Granada, Caja General de Ahorros de Granada, Colección literaria. 1992.

, Diez de últimas, Palma de Mallorca, Col·lecció poesía de paper, 1996.

, «The poetry of experience y la poesía española de los últimos quince años» en

LANGBAUM, R., La poesía de la experiencia, Granada, Comares, 1996, pp. 11-16. , Granada, 1900, Madrid, Sílex, 1997.

, El año en que mataron a Lennon, Castellón, Ayuntamiento de Castellón de La Plana, 1997.

, Un hombre suave, Madrid, Akal, 2000.

, Ahora, todavía, Sevilla, Renacimiento, 2001.

, Letra pequeña, Granada, Cuadernos del vigía, 2003.

- Las rosas artificiales (La búsqueda de la modernidad en la poesía hispánica), Sevilla, Fundación Genesian, 2003.

, El prisionero a muerte, Sevilla, Renacimiento, 2005.

- El impuro amor de las ciudades. Notas acerca de la literatura modernista y el espacio urbano, Madrid, Visor, 2006. 
, Suena una música. Antología 1971-2007 [prólogo de Ángel González], Sevilla, Renacimiento, 2007.

, El sueño de un reino, Granada, Mirto-Academia, 2007.

, Guía literaria de la ciudad de Granada. Itinerarios árabe y renacentista, Granada, Lavela, 2007.

, La canción del outsider, Madrid, Visor, 2009.

, En el mundo de los mundos, Granada, Traspiés, 2010.

, «Olor a espera», Granada hoy (24 de abril, 2011), s.p.

, «Otras puntualizaciones a Manuel Rico», Al margen (6 de mayo, 2011), s.p.

, Las artimañas del tiempo, Almería, Aula de Poesía del I.E.S. Rosa Navarro de Olula de Río. 2011.

, Fragmentos de Nueva York y otro poema, Granada, Los Cartones del Diente de Oro, 2012. , POPoemas, Granada, Dauro, 2014.

, Fumando con mis muertos, Sevilla, Vandalia, 2016.

SALVADOR, Á., y GEIST, A.L., Cartografía poética. 54 poetas españoles escriben sobre un poema preferido, Sevilla, Renacimiento, 2004.

SORIA OLMEDO, A., Literatura en Granada, 1898-1998. Volumen II, Poesía. Granada, Diputación de Granada, 2000.

WAHNÓN BENSUSAN, S., «La condición de ser personaje», Ideal (26 de junio, 1993), s.p. 